\title{
CHEMICAL AND LEAD ISOTOPE CHARACTERISATION OF FIRST WORLD WAR SHRAPNEL BALLS AND BULLETS USED ON THE ALPINE AUSTRIAN-ITALIAN FRONT
}

\author{
Vittoria Laterza ${ }^{1,3}$,Veronica Ros ${ }^{4}$, Clara Turetta ${ }^{4}$, \\ Jacopo Gabrieli ${ }^{4}$, Warren RL Cairns ${ }^{4}$, Eleonora Balliana ${ }^{5}$, \\ Carlo Baroni $^{3}$, Salvatore Maria Cristina ${ }^{3}$, Aldino Bondesan $^{1,2}$, \\ Carlo Barbante 4,5 .
}

1 Department of Historical and Geographic Sciences and the Ancient World - DiSSGeA, Wollemborg Palace, Geography Section, via del Santo, 26, 35123 Padova, Italy

2 Research Fellow, Department of Military Geography, Faculty of Military Science, Stellenbosch University

3 Department of Earth Sciences, University of Pisa, Via Santa Maria, 53, 56126 Pisa, Italy

4 Institute for the Dynamics of Environmental Processes-CNR, University Ca' Foscari of Venice, via Torino 155, 30172 Venice, Italy

5 Department of Environmental Science, Informatics and Statistics, University Ca' Foscari of Venice, via Torino 155, 30172 Venice, Italy

\begin{abstract}
Chemical and lead isotope characterisation was carried out on shrapnel balls and bullets dating back to the First World War (WWI). These ammunitions were widely utilised in the Alpine Austrian-Italian front located in the Italian Alps. The investigation has been performed using inductively coupled plasma quadrupole mass spectrometry equipped with an octopole reaction system (ORS-ICP-QMS). The main goal of this work was to identify the elemental and lead isotope composition of raw materials and to discriminate between the military objects analysed. The results of multi-elemental analysis indicate that the shrapnel ball samples consisted of soft $\mathrm{Pb}$ or hard $\mathrm{Pb}$ with $\mathrm{Sb}$ depending on the use, the weapon type and the specific nation. The Italian shrapnel balls were made from hard $\mathrm{Pb}$, as opposed to those of the AustrianHungarian samples. Through the investigation of lead isotope ratios, it has been possible to differentiate most of the Italian shrapnel balls from those of AustrianHungarian origin. Furthermore, some Italian shrapnel balls had a different lead isotope composition depending on their calibre. The elemental composition and lead isotopic signature of bullets show a clear discrimination between the external jacket and the core in relation to projectile type and nationality. The bullet cores consist of
\end{abstract}


$\mathrm{Pb}-\mathrm{Sb}$ alloy regardless of the region of origin. This work allowed us to investigate the potential applications of trace elements and lead isotope analyses to discriminate military artefacts of different origins.

Key words: ICP-MS, trace element, source identification, principal component analysis, forensic science.

\section{Research aims}

The aim of this work was to characterise and discriminate between shrapnel balls and bullets dating back to the First World War (WWI) according to their type, use and region of origin. The multi-elementary analysis and lead isotopic composition of these types of samples provide new insights and interesting data on the different raw materials used for the production of these types of munitions used by the Italian and Austrian-Hungarian armies during WWI. The combination of these two analytical techniques to study these types of objects could be a valuable tool for archaeological reconstructions and forensic science.

\section{Introduction}

One of the most lethal artillery munitions, extensively used in the European theatre of the First World War (WWI) was the Shrapnel shell (invented by Henry Shrapnel in 1784). This is a type of ogival-headed cylinder grenade with a cavity for the gunpowder charge and a large number of balls that are released on explosion in the air. It was widely utilised in the Austrian-Italian Alpine front that was located in the Italian Alps within the Adamello-Presanella, Ortles-Cevedale and Dolomiti mountain groups, on glacial and periglacial areas above 3,000 metres.

A Shrapnel shell was originally made of cast iron, but gradually its manufacturing materials, as well as its shape and design, were improved thanks to metallurgy innovations from the end of the $19^{\text {th }}$ century. ${ }^{1}$ These improvements led to the development of more lethal and effective weapons during WW1 (the Great War) (1914-1918). Despite these technical developments, during the Great War, shrapnel projectiles made previously and with different shapes and materials were also used, given the difficulty of weapon production. Iron shrapnel dating back to 1875 , steel shrapnel produced during the first years of the $20^{\text {th }}$ century, and grenade shrapnel from 1917 onwards, were all used during WWI (Figure 1). 


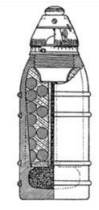

a

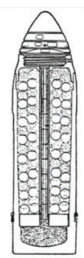

b

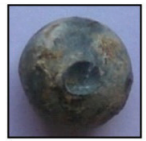

d

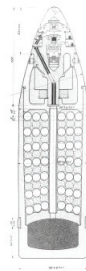

C
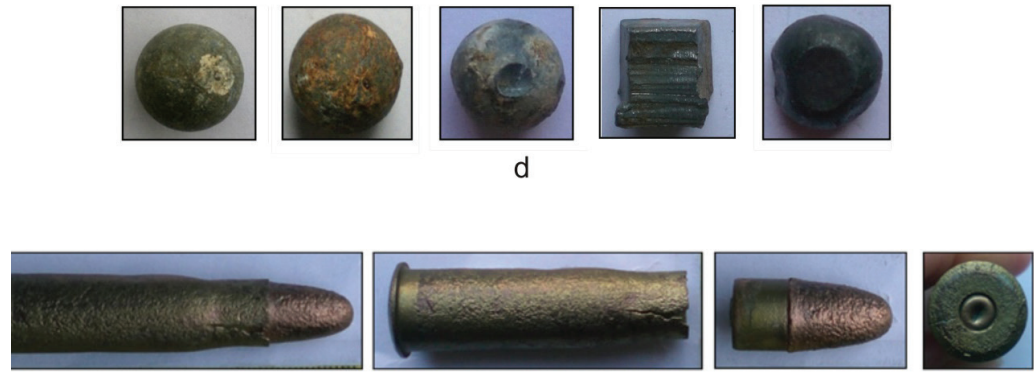

e

Fig. 1 Some examples of Shrapnels used during WWI: a) Iron shrapnel dated back to 1875, b) steel shrapnel produced in the first years of the 20th century, c) grenade shrapnel from 20thcentury (Marcuzzo, 2003); d) pictures of some shrapnel ball samples analyzed (samples 12, 23, 53, 62, 69); e) pictures of different parts of bullet sample 39.

The differences among these kinds of projectiles refer to the type, the number and the weight of the balls, for example, a $75 \mathrm{~mm}$ shrapnel projectile contained between 100 and 300 balls, each weighing between 10 and 16 g. ${ }^{2}$ These balls were made of Fe or $\mathrm{Pb}$, and sometimes of hardened $\mathrm{Pb}(\mathrm{Pb}$ and $\mathrm{Sb}$ alloy). They could differ, depending on the nation: in some French shrapnel projectiles, brass balls were also found. ${ }^{3}$ The exchange of weapons and war materials, including shrapnel shells, was frequent between cobelligerent nations. This was further complicated by the fact that large quantities of weapons and munitions captured from the enemy were widely used to exploit all the available raw materials and to rectify any chronic lack of munitions.

The application of analytical methods for the characterisation of historical objects of this type, and the determination of their source or geographical origin are appropriate in the context of archaeological recovery. Italian Law no. 78/2001, ${ }^{4}$ defines the status of cultural heritage for Great War finds, and museum conservation could help with historical and geographical interpretation.

Several studies using elemental fingerprinting methods (major, minor and trace elements) on a huge variety of samples have provided very valuable information. In addition to elemental concentrations, recent studies have relied upon the subtle 
differences in the $\mathrm{Pb}$ isotopic abundance present in the samples or objects investigated, in order to characterise a particular material and to use the value for provenance studies. Lead is one of the few elements for which the isotopic composition varies according to the place of origin. In fact, three of the four stable isotopes, ${ }^{206} \mathrm{~Pb}(24 \%)$, ${ }^{207} \mathrm{~Pb}(23 \%)$ and ${ }^{208} \mathrm{~Pb}(52 \%)$, are formed as end products of the radioactive decay of ${ }^{238} \mathrm{U},{ }^{235} \mathrm{U}$ and ${ }^{232} \mathrm{Th}$, respectively. The ${ }^{204} \mathrm{~Pb}$ isotope is the only primordial stable isotope with a constant abundance on earth over time. ${ }^{5}$ The isotopic composition of these elements in geological materials and the relative abundance of the different $\mathrm{Pb}$ isotopes depend on the relative concentration of the elements involved and the time during which they were together in the material. ${ }^{6}$ Therefore, the isotopic composition of $\mathrm{Pb}$ in the investigated samples will reflect the isotopic composition of its origin and thus it will vary according to the original composition of the ore body. Moreover, $\mathrm{Pb}$ isotopes are apparently not fractionated by industrial usage. ${ }^{7}$

In archeometry, these methods are used to determine the provenance of an archaeological object or the source of a material to characterise its transportation history. ${ }^{8}$ These methods are also used both in forensic science to provide useful information in crime and firearms investigations ${ }^{9}$ and in environmental research to determine sources of pollution. ${ }^{10}$ These fingerprinting methods are most often based on the use of inductively coupled plasma mass spectrometry (ICP-MS). Tamura ${ }^{11}$ has demonstrated that the lead isotope ratio measured by using a quadrupole ICP-MS was useful for a practical analysis of bullet samples in forensic science. The introduction of mass spectrometric measurement of the lead isotope ratios of ancient lead artefacts or bullets (and shotgun pellets) has revolutionised the study and characterisation of metals and the discrimination of their origin. Several studies have shown that a combination of chemical and lead isotope analysis is a powerful tool for this purpose. Although ICP-MS analyses do not achieve the precision and the accuracy of isotope ratio determinations obtained using thermal ionisation mass spectrometry (TIMS), several advantageous features make the use of ICP-MS a suitable alternative: fast sample throughput, low sample analysis cost, instrument robustness and simplified sample preparation. ${ }^{12}$ The multi-elemental capability, the sensitivity, and the dynamic range of ICP-MS make this instrument the ideal technique for trace element and isotope analysis of bullets, cartridge cases and $\mathrm{Pb}$ artillery shots. ${ }^{13}$

In this study, shrapnel balls dating back to WWI from the Austrian-Italian Alpine front were analysed by ICP-MS, equipped with an octopole reaction system (ORSICP-QMS), to determine the chemical composition (major, minor and trace elements) and lead isotope ratios. These samples have both known (Italian, Austrian-Hungarian) and unknown origins. Furthermore, investigations have also been conducted on some types of bullets of known origin for different arms (rifles and side arms), dating back to WWI that were used on the Austrian-Italian Alpine front.

The main goal of this work was to identify the elemental and lead isotopic composition of the raw materials and to discriminate among the analysed war objects. 


\section{Materials and methods}

A total of 13 shrapnel balls and 15 bullet samples provided by the Italian War History Museum of Rovereto (Trento, Italy) and 28 shrapnel ball samples collected by the authors and other experts on the Italian and Austrian-Hungarian front were analysed (Figure1).

Three shrapnel balls from seven types of selected projectiles, dating from WWI with different origins (Italian or Austrian-Hungarian) were taken, making a total of 21 shrapnel balls of known origin (sample codes 51-71, Table 1). The types of selected projectiles were three shrapnel projectiles originating from 1875, two steel shrapnels dating back to the beginning of the $20^{\text {th }}$ century and Italian shrapnel and Austrian grenade shrapnel originating from 1917. Twenty undated shrapnel balls of unknown national origin (sample codes 1,3-5 and 12-27, Table 1) were also analysed. Moreover, 15 bullets (Table 2) for different models and types of firearm used by the Italian and Austrian-Hungarian armies during WWI were also investigated.

Table 1 Description of the shrapnel ball samples.

\begin{tabular}{|c|c|c|}
\hline Sample Code & Description & Origin \\
\hline $1,3-5,12-14^{*}$ & Shrapnel ball & $\begin{array}{l}\text { Unknown, } \\
\text { Marmolada Glacier (BL) }\end{array}$ \\
\hline $15-27^{* *}$ & Shrapnel ball & $\begin{array}{l}\text { Unknown, } \\
\text { Trentino Alto Adige }\end{array}$ \\
\hline $51,52,53^{*}$ & $\begin{array}{l}\text { Shrapnel ball for shrapnel projectile, caliber } \\
75 \mathrm{~mm} \text {. Dated back to } 1875\end{array}$ & Italian \\
\hline $54,55,56^{*}$ & $\begin{array}{l}\text { Shrapnel ball for shrapnel projectile, caliber } \\
120 \mathrm{~mm} \text {. Dated back to } 1875\end{array}$ & Italian \\
\hline $57,58,59^{*}$ & $\begin{array}{l}\text { Shrapnel ball for shrapnel projectile, caliber } \\
75 \mathrm{~mm} \text {. Dated back to beginning of the } 20^{\text {th }} \\
\text { century. Reproduction of drawings at end of } \\
\text { the } 19^{\text {th }} \text { century. }\end{array}$ & Italian \\
\hline $60,61,62^{*}$ & $\begin{array}{l}\text { Shrapnel ball for shrapnel projectile Pancani, } \\
\text { caliber } 105 \mathrm{~mm} \text { Dated back to } 1917\end{array}$ & Italian \\
\hline $63,64,65^{*}$ & $\begin{array}{l}\text { Shrapnel ball for shrapnel projectile, caliber } \\
150 \mathrm{~mm} \text { Dated back to } 1875\end{array}$ & Austrian \\
\hline $66,67,68^{*}$ & $\begin{array}{l}\text { Shrapnel ball for shrapnel projectile, caliber } \\
75 \mathrm{~mm} \text {. Dated back to beginning of the } 20^{\text {th }} \\
\text { century. Reproduction of drawings at end of } \\
\text { the } 19^{\text {th }} \text { century. }\end{array}$ & Austrian \\
\hline $69,70,71^{*}$ & $\begin{array}{l}\text { Shrapnel ball for shrapnel projectile, caliber } \\
\text { 100mm M15 Brisant Granate. Dated back to } \\
\text { 1917. German production. }\end{array}$ & Austrian \\
\hline
\end{tabular}

*Shrapnel balls collected on Italian and Austro-Hungarian Alpine front.

**Samples provided by Italian War Historical Museum of Rovereto (Trento, Italy). 
Table 2 Description of the bullet samples.

\begin{tabular}{|c|c|c|c|c|}
\hline $\begin{array}{c}\text { Sample } \\
\text { Code }\end{array}$ & Description & Origin & Year & $\begin{array}{c}\text { Average size } \\
(\mathrm{mm})\end{array}$ \\
\hline $29^{* *}$ & $\begin{array}{l}\text { Cartridge } 8 \mathrm{~mm} \text { Mannlicher } \\
\text { (Mannlicher M95 rifle). Lead bullet } \\
\text { with nickel-plated steel external jacket } \\
\text { and brass case. }\end{array}$ & Austrian & 1888 & $8.15 * 50.3$ \\
\hline $31^{* *}$ & $\begin{array}{l}\text { Bullet for } 8 \mathrm{~mm} \text { Mannlicher cartridge. } \\
\text { Lead bullet with nickel-plated steel } \\
\text { external jacket. }\end{array}$ & Austrian & 1888 & Caliber 8.15 \\
\hline $32,33^{* *}$ & $\begin{array}{l}\text { Cartridge } 6.5 \mathrm{~mm} \text { Carcano } \\
\text { (Mannlicher - Carcano M91 rifle). } \\
\text { Lead bullet with cupronickel external } \\
\text { jacket and brass case. }\end{array}$ & Italian & 1895 & $6.75 * 52.3$ \\
\hline $34,35^{* *}$ & Cartridge rifle, with case and bullet & Italian & & $6.75 * 52.3$ \\
\hline $36^{* *}$ & $\begin{array}{l}\text { Cartridge } 6.5 \mathrm{~mm} \text { Carcano } \\
\text { (Mannlicher - Carcano M91 rifle). } \\
\text { Lead bullet with cupronickel external } \\
\text { jacket and brass case. }\end{array}$ & Italian & 1895 & $6.75 * 52.3$ \\
\hline $38-40^{* *}$ & $\begin{array}{l}\text { Cartridge } 10.4 \mathrm{~mm} \text { (Vetterli rifle). } \\
\text { Lead bullet with brass external jacket } \\
\text { and case. }\end{array}$ & Italian & 1870 & $10.75 * 47.4$ \\
\hline $42^{* *}$ & $\begin{array}{l}\text { Cartridge } 8 \mathrm{~mm} \text { Mannlicher } \\
\text { (Mannlicher M95 rifle). Lead bullet } \\
\text { with nickel-plated steel external jacket } \\
\text { and brass case. }\end{array}$ & Austrian & 1888 & $8.15 * 50.3$ \\
\hline $47^{* *}$ & $\begin{array}{l}\text { Cartridge } 10.4 \mathrm{~mm} \text { Glisenti (Glisenti } \\
\text { revolver). Armoured brass bullet with } \\
\text { brass case. }\end{array}$ & Italian & & \\
\hline $48,49^{* *}$ & $\begin{array}{l}\text { Cartridge } 9 \mathrm{~mm} \text { Glisenti (Glisenti } \\
\text { revolver model 1910). Armoured brass } \\
\text { bullet with brass case. }\end{array}$ & Italian & & $8.96 * 19$ \\
\hline $50^{* *}$ & $\begin{array}{l}\text { Cartridge } 9 \text { mm Steyr gun (model } \\
\text { 1911). Lead bullet with steel external } \\
\text { jacket and brass case. }\end{array}$ & Austrian & 1911 & $9.00 * 22.9$ \\
\hline
\end{tabular}

** Samples provided by Italian War Historical Museum of Rovereto (Trento, Italy).

All analyses were performed at the laboratory of the Department of Environmental Sciences, Computer Science and Statistics, University of Ca Foscari, Venice, Italy and the Institute for the Dynamics of Environmental Processes of National Research Council (IDPA-CNR), Venice, Italy. 


\section{Sample preparation}

The selected samples, made of metallic materials, were characterised by a heterogeneous oxidised surface layer with different encrustations. The samples were mechanically cleaned using brushes, spatulas and scalpels in order to remove any surface contamination due to soil, organic components and corrosion products to sample the original material. Particularly adherent surface encrustations were removed using deionised water to limit any damage to the samples. Each sample was cleaned with ethanol to remove all organic materials and then dried.

Three representative subsamples were taken from each sample using a batterypowered drill, with a 1 or $2 \mathrm{~mm}$ stainless steel bit (decontaminated in an ultrasonic cleaning bath for 5 minutes). In this way, a mixture of fine powder and shavings was obtained for each sample.

A double sampling was performed for bullets with different compositions between the central core and the jacket. The inner core (a) and the external jacket (b) were treated individually for both elemental and isotopic analysis (Figure 1).

To determine the elemental composition and isotope ratios, about 100 to $200 \mathrm{mg}$ of pulverised sample was digested by using a closed digestion procedure in about $15 \mathrm{ml}$ of supra pure $\mathrm{HNO}_{3}(65 \%$; Merck KGaA, Darmstadt, Germany) and ultra pure water (obtained by coupling a Purelab-Option with a Purelab-Ultra system from ELGAVivendi Water Systems, Bucks, UK), until complete crystallisation of the sample. The resulting solutions were diluted to $50 \mathrm{ml}$ (by weight) in clean polypropylene centrifuge tubes. The samples were kept frozen at $-20{ }^{\circ} \mathrm{C}$ until analysis. Sample preparation was performed in a Class 100 Clean Room Laboratory in order to reduce any possible sample contamination.

\section{Analytical method}

Major elements ( $\mathrm{Pb}, \mathrm{Sb}, \mathrm{Fe}, \mathrm{Ni}, \mathrm{Cu}, \mathrm{Zn}$ ), trace elements (Li, Be, Mg, Al, Ti, V, Cr, Mn, Fe, Co, Ni, Cu, Zn, Ga, As, Se, Rb, Sr, Mo, Ag, Cd, Sn, Sb, Cs, Ba, Tl, Pb, Bi, U) and $\mathrm{Pb}$ isotopes $\left({ }^{204} \mathrm{~Pb},{ }^{206} \mathrm{~Pb},{ }^{207} \mathrm{~Pb},{ }^{208} \mathrm{~Pb}\right)$ were determined by quadrupole ICP-MS, equipped with an octopole reaction system, Agilent 7500cx (Agilent Technologies, Yokogawa Analytical Systems, Tokyo, Japan), with a quartz double pass spray chamber, thermostated to $2{ }^{\circ} \mathrm{C}$, and fitted with a concentric low flow $\left(<500 \mu 1 \mathrm{~min}^{-1}\right)$ nebuliser (Elemental Scientific Inc, Omaha).

The quantification of major and trace elements was made by external calibration, using solutions prepared gravimetrically from more concentrated certified standard solutions, containing the analytes of interest at a concentration range from $0.97 \mu \mathrm{g} / \mathrm{L}$ to $1083 \mu \mathrm{g} / \mathrm{L}$. The standard for trace elements was ICUS 2012 (Ultra Scientific, USA - inorganic custom standard, 30 analytes, $10 \mu \mathrm{g} / \mathrm{mL}$, in water with dilute $\mathrm{HNO}_{3}, 5 \%$ ). A second series of standards has been made for $\mathrm{Sn}$, $\mathrm{Ti}$ and $\mathrm{Cs}$, which are not present in the ICUS 2012. The internal standard used was Xenon (129), which is present as an impurity in the argon of the instrument and not present in the samples (as it is a gas) to monitor instrumental sensitivity drift during the analytical run. 
Several reagent blanks for each kind of sample were processed to calculate the instrumental detection limit (3x SD of the blank). Data collected from each analysis were corrected for the blank digestion value and the specific dilution factor. Seven shrapnel ball samples were used to check the reproducibility of the method in the absence of a certified material of a similar composition to the samples analysed. Three subsamples were taken, at different points of the sample, and were analysed separately. The average concentration has been calculated for each element, and the mean relative standard deviation ( $\mathrm{RSD} \%$ ) was found to be $<15 \%$, except for $\mathrm{Li}, \mathrm{Mg}$, $\mathrm{Ni}, \mathrm{Se}, \mathrm{Mo}, \mathrm{Sn}, \mathrm{Sb}$ where the RSD was between 15 and $20 \%$.

Before quantitative analysis, a semi-quantitative determination of the metals present was performed using a 23-element $90 \mu \mathrm{g} / \mathrm{L}$ multi-element standard. This was done to obtain a clearer idea of the elements present and the order of magnitude of their concentrations, to optimise the method, choose the standards for calibration and to dilute the digests sufficiently to remain in the linearity of the instrument. This preliminary analysis showed that the original material of the samples was quite heterogeneous. Based on this semi-quantitative analysis, aliquots of the principal solutions were diluted 1:10000 to quantify all the important elements in one analytical run, making full use of the linearity of the ICP-MS instrumentation.

A sample of SRM 981 common lead isotopic standard (NIST, Gaithersburg, MD, USA) was dissolved in cold $1: 1(\mathrm{v} / \mathrm{v})$ diluted $\mathrm{HNO}_{3}(65 \%)$, which was diluted to give a concentration of $50 \mathrm{mgL}^{-1}$. This was then diluted to a total lead concentration of $10 \mu \mathrm{g}$ $\mathrm{L}^{-1}$ to be used as a mass bias correction solution for isotope ratio analysis. This in turn was used as a bracketing standard for every four samples to check the mass bias of the isotopic analysis. Each measurement is the average of six replicates. The calculated RSD was $<0.5 \%$. For isotope ratio analysis, each solution was diluted in order to obtain a solution with a lead content of $<10 \mu \mathrm{g} \mathrm{L}^{-1}$ for the ICP-MS measurement to ensure that all measurements were carried out in the pulse-counting detection mode.

\section{Elaboration of results}

The experimental data were elaborated by using multivariate statistical analysis. Principal component analysis (PCA) and hierarchical clustering analysis (HCA) were applied to the dataset (major, minor and trace element concentrations as well as lead isotope ratios) to evaluate the different characteristics of the samples. This analysis was performed by using the software package Statistica (StatSoft Inc., Tulsa, OK, USA) and UNISTAT (UK).

\section{Results and discussion}

In this section we discuss the chemical analysis of shrapnel balls and of bullets as well as discuss the results of lead isotope analysis. 


\section{Shrapnel balls - chemical analysis}

The results of the elemental analyses of the shrapnel ball samples are presented in Table 3.

Lead was the major component of most of the shrapnel ball samples, with a mean concentration of $92.95 \%$ and a range between $83.87 \%$ and $96.95 \%$ (samples $24-27$ were excluded). These lead samples were either very pure soft $\mathrm{Pb}$, or $\mathrm{Pb}$ hardened with $\mathrm{Sb}$. The content of this element varied from a minimum of $0.15 \%$ to a maximum of $12.60 \%$ and had a mean value of $3.82 \%$. The soft $\mathrm{Pb}$ might have consisted of very pure virgin $\mathrm{Pb}$, or moderately pure recycled $\mathrm{Pb}$, as shown by the chemical composition of the sample, or a mixture of both types. It can contain from less than 1 $\operatorname{ppm}(0.0001 \%)$ to about $1500 \mathrm{ppm}(0.15 \%)$ of Sb naturally depending on the ore. On the other hand, hard $\mathrm{Pb}$ is an industrial alloy with $\mathrm{Sb}$ levels between $0.4 \%$ and $12 \%$, depending on the type and the function of the weapon. ${ }^{14}$

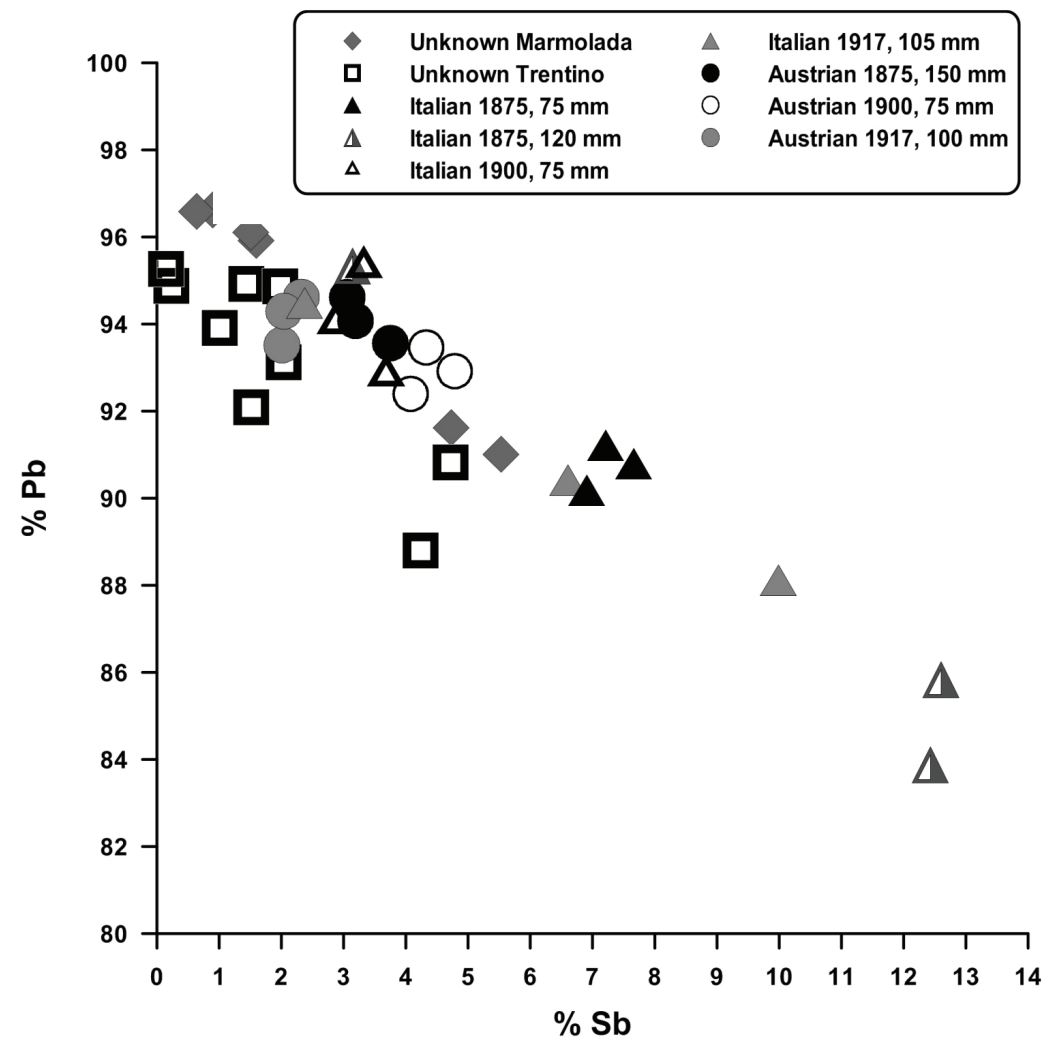

Fig. 2 Scatterplot $\% \mathrm{~Pb}$ vs. \% $\mathrm{Sb}$ in shrapnel balls samples, without samples with high Fe \% (24-27). 
In Figure 2, the percentages of $\mathrm{Pb}$ and $\mathrm{Sb}$ in the analysed samples are compared. The samples have different compositions, depending on their origin, the time of use and the type of projectile. Sb varied from a minimum of about $2 \%$ to a maximum of 5\% in the Austrian-Hungarian samples and between about 3\% and $13 \%$ in the Italian samples, showing that Italian shrapnel balls of $1875(75 \mathrm{~mm}$ and $120 \mathrm{~mm})$ and $1917(105 \mathrm{~mm})$ contained hardened $\mathrm{Pb}$ with $\mathrm{Sb}$ levels higher than the AustrianHungarian samples. The $\mathrm{Pb}$ and $\mathrm{Sb}$ concentrations were less variable in the AustrianHungarian samples, although they had different ages. Furthermore, the Italian samples had different levels of these two elements even between balls retrieved from the same shrapnel projectile. The three Italian balls (57-59) from a $75 \mathrm{~mm}$ calibre shell manufactured in 1900 showed similar concentrations to Austrian-Hungarian samples as did samples $54(120 \mathrm{~mm}, 1875)$ and 61 (105 mm, 1917). With the exception of these samples, our results support those reported by Marcuzzo that higher values of Sb were found in Italian shrapnel balls. All the samples of unknown origin had values of $\mathrm{Sb}$ that varied but remained lower than $6 \%$. Some samples collected on the Marmolada Glacier had the highest values (average 95\%) for $\mathrm{Pb}(3-5,12,14)$. Most of the Trentino samples of unknown origin had $\mathrm{a} \mathrm{Pb}$ and $\mathrm{Sb}$ composition very similar to Austrian-Hungarian shrapnel balls of 1917.

Some samples (24-27), collected in Trentino Alto Adige, were composed of Fe with a range of $90-97 \%$ and an average of $94 \%$. They contained significant traces of $\mathrm{V}$ (average of $1.2 \mathrm{mg} / \mathrm{g}$ ), $\mathrm{Mg}$ and $\mathrm{Ba}$ (mean values of 4.1 and $8.8 \mathrm{mg} / \mathrm{g}$ respectively). References by Marcuzzo confirm the possible use of cast iron or other alloys of Fe for the production of shrapnel. ${ }^{15}$

In order to evaluate the similarities or differences in composition of the analysed samples, PCA was applied on a data set of 41 samples with 26 variables ( $\mathrm{Li}, \mathrm{Be}, \mathrm{Mg}$, Al, Ti, V, Cr, Mn, Ni, Cu, Zn, Ga, As, Rb, Sr, Mo, Ag, Cd, Sn, Sb, Cs, Ba, Tl, Pb, $\mathrm{Bi}, \mathrm{U})$. Before applying the PCA, standardisation of the variables was performed. $\mathrm{Fe}, \mathrm{Co}$ and $\mathrm{Se}$ were found to be insignificant, as there were too many values below the detection limit (Table 3). The first two PCs covered 59\% of the total variance. In the score plot (Figure 3), PC1 and PC2 show a clear distinction between samples of different origins. 


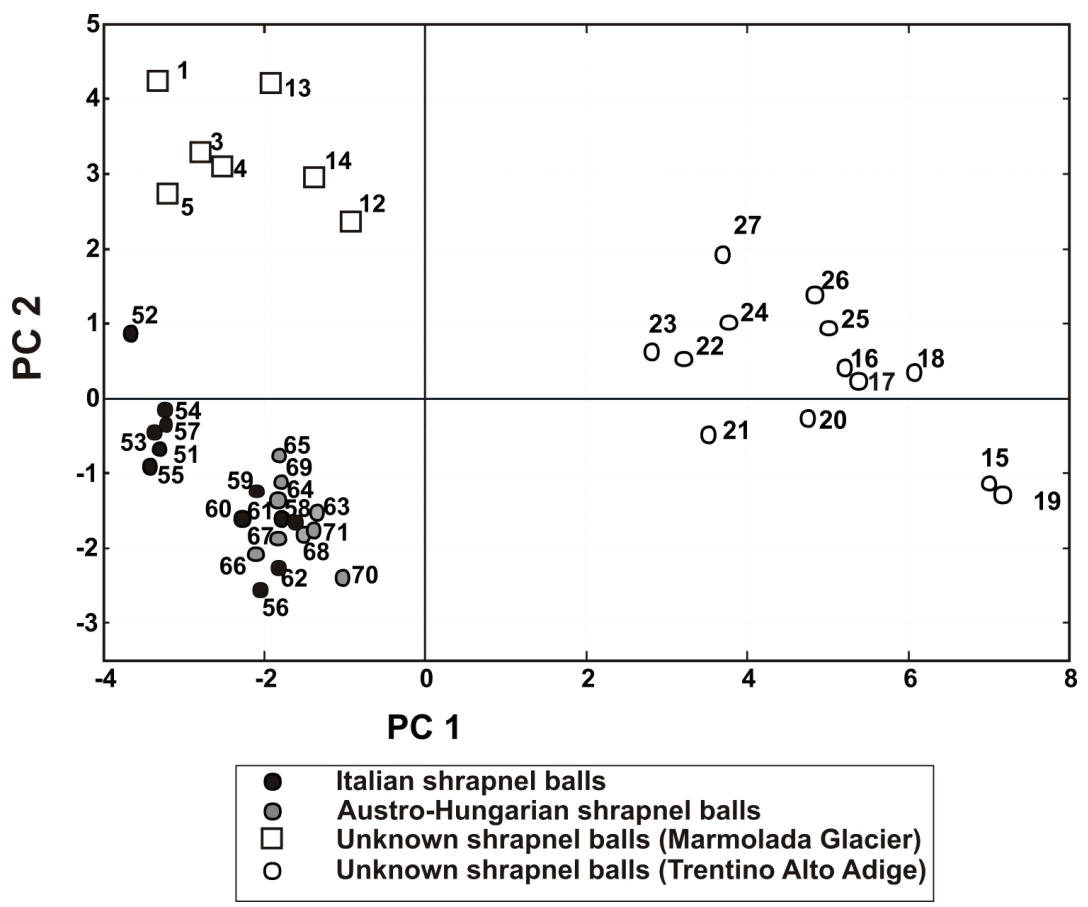

Fig. 3 Score plot of the shrapnel ball samples on the PC1 (46\% of explained variance) vs PC2 (13\% of explained variance).

PC1 explained $46 \%$ of the dataset variance and separated the samples of Trentino origin from the others as highlighted by their high positive scores on the first principal component. They had high positive scores on the first principal component. All the Austrian-Hungarian samples had negative scores on PC1 and PC2 and they were clustered with the Italian samples of different ages and types $(56,58-59,60-62)$. The other Italian samples were distinctive and had a higher negative weight on PC1 (all samples from 1875, except sample 56, and sample 57 from 1900). Sample 52 had a slightly higher score on PC2. The shrapnel balls from Marmolada had a negative score on $\mathrm{PC} 1$ and a positive score on PC2, representing two subgroups (1, 3-5 and 12-14).

The loading plot of variables (Figure 4) on $\mathrm{PC} 1$ and $\mathrm{PC} 2$ shows that $\mathrm{Sb}$ and $\mathrm{Pb}$ had negative scores on PC1 and PC2. They marked all Austrian-Hungarian samples and Italian samples $(56,58-59,60-62)$. Some Italian balls (51-55 and 57) were characterised by $\mathrm{Tl}, \mathrm{Mo}, \mathrm{Ag}, \mathrm{Bi}, \mathrm{Mn}$ with high negative scores on PC1. Li, Ga, $\mathrm{Sr}$, $\mathrm{Cd}, \mathrm{Ba}, \mathrm{Al}$ and $\mathrm{Zn}$ were the dominant elements in the positive sector of $\mathrm{PC} 1$ and these discriminated the samples from Trentino. $\mathrm{V}, \mathrm{Be}$ and $\mathrm{Cr}$ on $\mathrm{PC} 1$ select samples from Trentino with high Fe levels (24-27). Bi, Mn, Ni, As and $\mathrm{Cu}$ on PC2 characterised the samples from the Marmolada Glacier. 


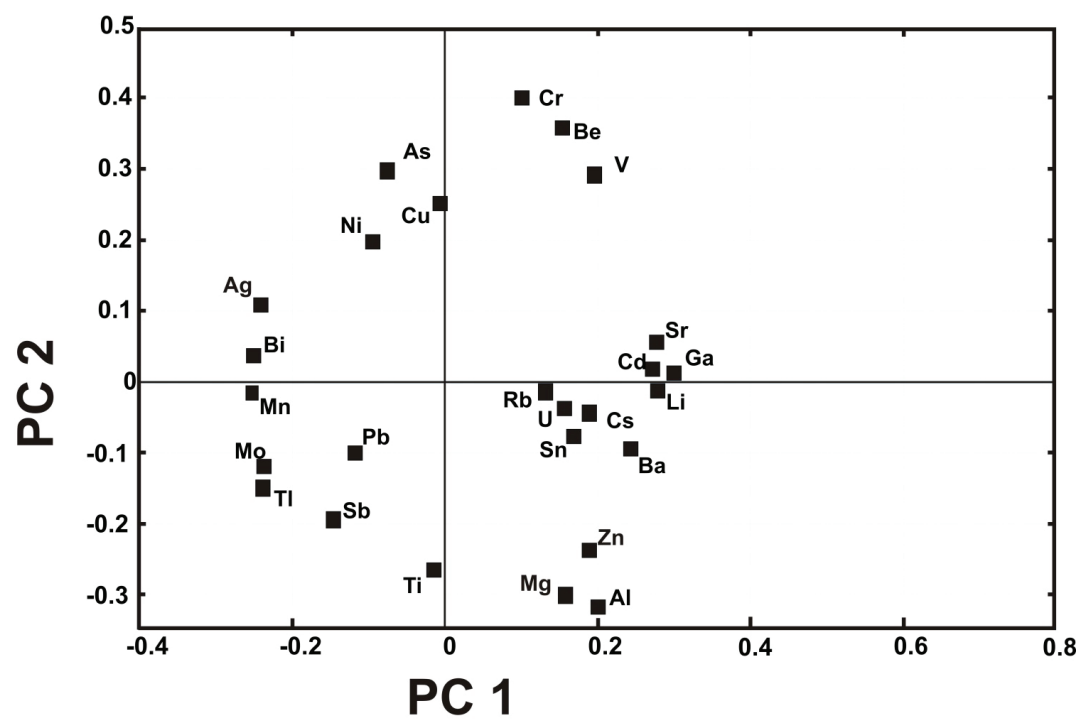

Fig. 4 Loading plot of the variables on the first and the second Principal Component.

This type of data processing confirmed that the Austrian-Hungarian samples had a homogeneous composition, unlike the Italian samples. For these latter shrapnel balls, it was assumed that a mix of raw materials had been used.

\section{Lead isotope analysis}

The isotope abundance measurements are reported in Table 4. The reported isotopic ratios considered were ${ }^{208 / 207} \mathrm{~Pb}$ and ${ }^{206 / 207} \mathrm{~Pb}$. Samples (24-27), with high levels of Fe, were not considered as they contained little lead. About $86 \%$ of the source discrimination power was due to the ${ }^{206} \mathrm{~Pb},{ }^{207} \mathrm{~Pb}$ and ${ }^{208} \mathrm{~Pb}$ isotopes. ${ }^{16}$ Since the ratios of lead isotopes did not change during metallurgical processes or chemical reactions, the origin of the metal could be defined uniquely, except where mixing of metals from different provenances occurred. ${ }^{17}$ Often, during the First World War, material recovered from the battlefield or war booty was fused and used as a source of metals. The determination of the origin of a specific object was therefore complicated by recycling and re-melting of metals.

In Figure 5, we report the experimental data relative to ${ }^{208} \mathrm{~Pb} /{ }^{207} \mathrm{~Pb}$ and ${ }^{206} \mathrm{~Pb} /{ }^{207} \mathrm{~Pb}$ isotopic ratios of the lead-based shrapnel balls. In accordance with the multi-elemental analysis, the samples of Austrian-Hungarian origin had a very narrow range of the lead isotope values $\left({ }^{208 / 207} \mathrm{~Pb}\right.$ of $2.456-2.477$ and ${ }^{206 / 207} \mathrm{~Pb}$ of $\left.1.171-1.193\right)$. The samples dating back to 1900 and 1917 possibly originated from similar mining sites, but were different from those dating back to 1875 . There was evidence for higher $\mathrm{Pb}$ isotopic variability $\left({ }^{208 / 207} \mathrm{~Pb} 2.429-2.472 ;{ }^{206 / 207} \mathrm{~Pb} 1.152-1.188\right)$ looking at the Italian samples according to the year and the type of weapon. 


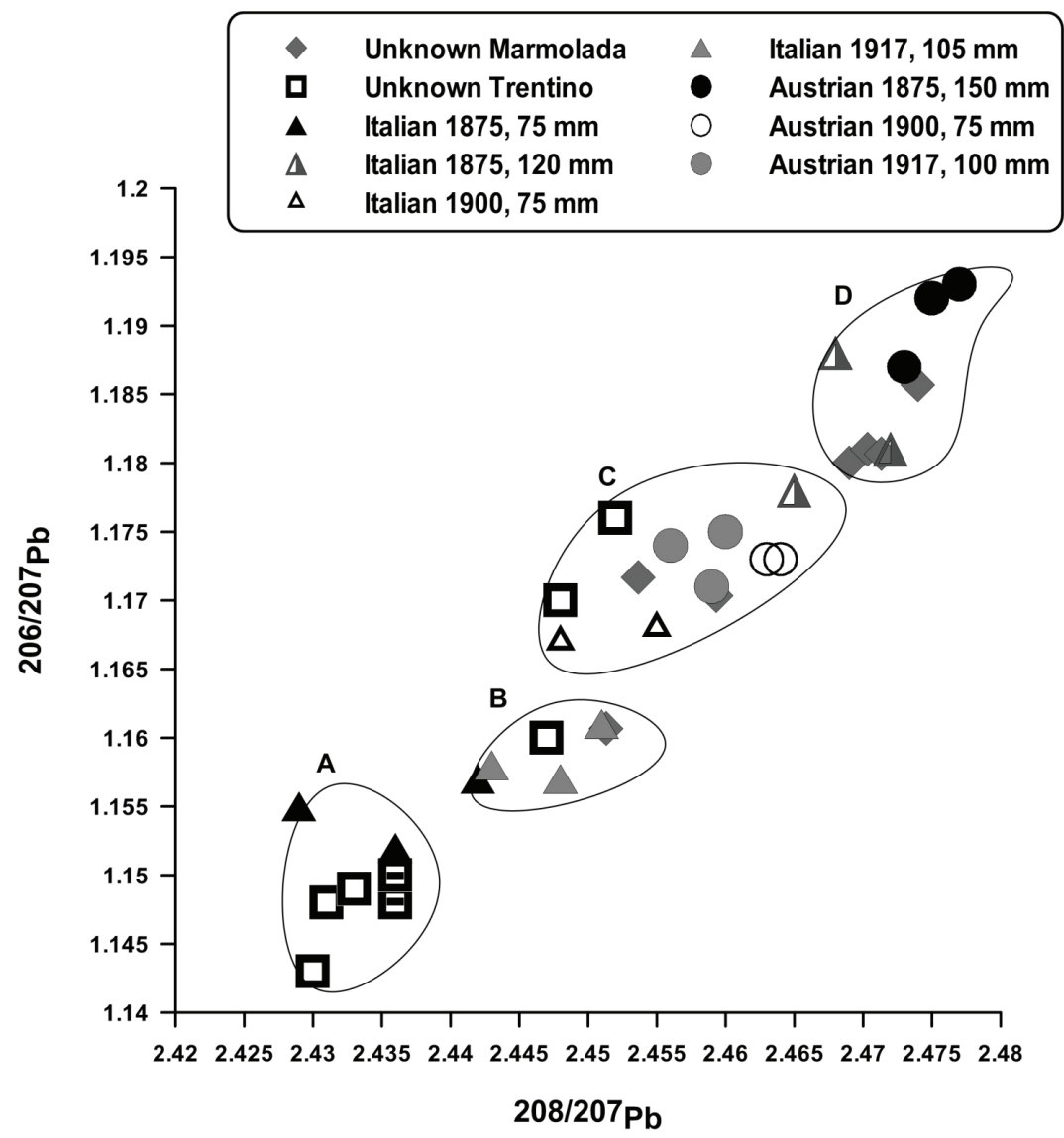

Fig. 5 Lead isotope abundance ratio values 208/207Pb vs 206/207Pb for lead shrapnel ball samples.

Cluster analysis of the lead isotope ratio data was carried out for grouping the samples according to the similarity in the data using Ward's method as agglomerative clustering and Euclidean distances as a similarity measure. ${ }^{18}$ Four different groups were found, nominated as A, B, C and D. Group A consisted of two Italian shrapnel balls (51 and 53), belonging to a $75 \mathrm{~mm}$ calibre projectile, dating back to 1875 . A further five samples from Trentino Alto Adige (15-20) had comparable lead isotopic ratios, which could identify their Italian origin from an 1875 projectile. The PCA showed different characteristics compared to the shrapnels of unknown origin considering the variables $\mathrm{Li}, \mathrm{Ga}, \mathrm{Sr}, \mathrm{Cd}$ and $\mathrm{Ba}$. Group B consisted of four samples of Italian origin (sample 52, taken from a $75 \mathrm{~mm}$ calibre projectile from 1875; 60-62 from a 105 $\mathrm{mm}$ calibre projectile) and two samples of unknown origin, one recovered from the 
Marmolada Glacier (14) and one from Trentino Alto Adige (23). Based on Pb isotopic data, these shrapnel balls had an Italian origin, but this data are not confirmed by the results obtained by PCA. The most heterogeneous group was $\mathrm{C}$, which was composed of Italian shrapnel balls from $75 \mathrm{~mm}$ calibre projectiles, dating back to 1900 (57-59) and $120 \mathrm{~mm}$ projectiles from 1875 (56); Austrian-Hungarian samples for $75 \mathrm{~mm}$ calibre projectiles from 1900 and $100 \mathrm{~mm}$ projectiles from 1917. This cluster was also confirmed by the PCA. The large variability in the Pb isotopic composition of the Italian samples suggested a possible use of recycled $\mathrm{Pb}$ by the Italian armies from captured ammunition. This group also included several samples of unknown origin (4 and 5 from the Marmolada Glacier, and 22 and 21 from the Trentino Alto Adige region), for which attribution of origin was not clear. Italian shrapnel balls for 120 mm calibre projectiles dating back to $1875(54,55)$ belonged to group $\mathrm{D}$, together with three samples of unknown origin (1, 3 and 12). Their $\mathrm{Pb}$ isotope ratios were very similar to sample $55\left({ }^{208 / 207} \mathrm{~Pb} 2.472 ;{ }^{206 / 207} \mathrm{~Pb} 1.181\right)$. We assumed a probable Italian origin for these samples, although they were distinct from elements with a high positive score on PC2 (As, Ni and $\mathrm{Cu}$ ). Associated with this group were the Austrian-Hungarian $150 \mathrm{~mm}$ calibre balls from 1875 (63-65) and sample 13 found on the Marmolada Glacier. The Austrian-Hungarian origin of this sample was confirmed by macroscopic analysis.

\section{Chemical analysis of bullets}

Table 5 reports the elemental concentrations of the core (a) and external jacketing (b) of the investigated bullets.

The inner core of the projectiles consisted of soft $\mathrm{Pb}$ or lead hardened with $\mathrm{Sb}$. The $\mathrm{Pb}$ average value was $96.21 \%$ and varied from $94.74 \%$ to $98.50 \%$, and an average $\mathrm{Sb}$ content of $0.43 \%$.

Only Austrian-Hungarian bullet cores from $8 \mathrm{~mm}$ Mannlicher cartridges (29a, 31a, 42a) and a $9 \mathrm{~mm}$ Steyr cartridge (50a) had an $\mathrm{Sb}$ concentration $>1 \%$. Even though they had a very similar composition to Italian samples, bullets of AustrianHungarian origin had a $\mathrm{Pb}-\mathrm{Sb}$ alloy core. Italian bullets had soft $\mathrm{Pb}$ cores and higher $\mathrm{Ni}$ (mean of $0.13 \%$ ), $\mathrm{Cu}$ (mean of $0.38 \%$ ) and $\mathrm{Mo}$ (mean of $0.52 \mathrm{mg} / \mathrm{g}$ ) concentrations.

Moreover, Italian and Austrian-Hungarian pistol bullet cores were characterised by higher contents of As (mean of $0.59 \mathrm{mg} / \mathrm{g}$ ), Ag (mean of $2.50 \mathrm{mg} / \mathrm{g}$ ), Bi (mean of $0.80 \mathrm{mg} / \mathrm{g}$ ) and $\mathrm{Rb}$ (mean of $0.71 \mathrm{mg} / \mathrm{g}$ ) compared to the cores of rifle bullets.

The external jacket composition varied in relation to the type of projectile and to the specific nation.

Fe was the most abundant element in the Austrian-Hungarian projectiles (29b, $31 \mathrm{~b}, 42 \mathrm{~b}$ and $50 \mathrm{~b}$ ), with a range of $55.7-100 \%$ and an average of $84 \%$. Sample $39 \mathrm{~b}$ (Italian $10.4 \mathrm{~mm}$ cartridge for a Vetterli rifle) was the only one with a $\mathrm{Pb}$ jacket. The Italian external jacket of Mannlicher-Carcano M91 rifle bullets (32b, 33b) had high contents of $\mathrm{Cu}$ (about 85-100\%) and $\mathrm{Ni}$ (about 14-18\%) but low levels of $\mathrm{Zn}$. They 
consisted of cupro-nickel (copper-nickel) (a Cu-Ni-Zn alloy), as reported by Mötz. ${ }^{19}$ Instead, the data showed a different composition for Vetterli rifle bullets and Glisenti revolver bullet jackets (38b, 40b-49b). They had a Cu mean concentration of $70 \%$ and $\mathrm{Zn}$ about $33 \%$. These types of weapons had a bullet with a brass jacket.

\section{Lead isotope analysis}

$\mathrm{Pb}$ isotope ratio measurements were performed on the core and on the external jackets of the projectiles. The results are presented in Table 6.

Bullet core samples had ${ }^{208 / 207} \mathrm{~Pb}$ values from 2.434 to 2.456 and ${ }^{206 / 207} \mathrm{~Pb}$ from 1.143 to 1.171 . These observed variations of the core samples did not allow for accurate determination of weapon type or specific nationality. During WWI, weapons and ammunition taken from the enemy troops were often used or were fused to produce other war objects, including cartridges. ${ }^{20}$ The use of recycled raw materials seems to have been valid, especially for the core of the projectiles. This was confirmed both by historic information ${ }^{21}$ and by macroscopic observation of the structure of the projectiles investigated. The external jacket, which represented the most important part of a bullet, had different technical characteristics and a different chemical composition depending on the type of weapon but also on the country of production. It was principally made of higher-quality materials using non-recycled metal from definite sources. The external jacketing of Italian and Austrian-Hungarian samples were well discriminated, based on their $\mathrm{Pb}$ isotope ratio values. Independently of the weapon type, the jackets of the Austrian-Hungarian samples 29b, 31 b (bullet for Mannlicher M95 rifle) and 50b (bullet for $9 \mathrm{~mm}$ Steyr pistol) had similar Pb isotopic ratios ( $\left.{ }^{208 / 207} \mathrm{~Pb} 2.425-2.432 ;{ }^{206 / 207} \mathrm{~Pb} 1.145-1.149\right)$.

For samples $32-35,47$ and 48 , analogous value are observed $\left({ }^{208 / 207} \mathrm{~Pb} 2.444-\right.$ 2.454; $\left.{ }^{206 / 207} \mathrm{~Pb} 1.158-1.164\right)$. These samples belonged to Italian bullets for $6.5 \mathrm{~mm}$ Carcano rifles (Mannlicher-Carcano M91) and $9 \mathrm{~mm}$ Glisenti cartridges (Glisenti revolver model 1910) respectively.

The two samples, $40 \mathrm{~b}$ and $38 \mathrm{~b}$, are bullets for an Italian Vetterli rifle of 10.4 $\mathrm{mm}$ calibre. They have different $\mathrm{Pb}$ isotopic ratios $\left({ }^{208 / 207} \mathrm{~Pb} 2.466-2.472 ;{ }^{206 / 207} \mathrm{~Pb}\right.$ 1.179-1.18) compared to the external jacket of the other Italian bullets. The $\mathrm{Pb}$ from a different mineral deposit or recycled material was probably used.

\section{Conclusion}

This article presented the results of chemical and lead isotope characterisation of shrapnel balls and some bullet types dating back to WWI that were used on the Austrian-Italian Alpine front. The work reported here allowed us to investigate the potential applications of trace elements and lead isotope analyses to discriminate war objects with different origins. The use of an ICP-MS instrument has the advantage of obtaining a large amount of information without a complex pre-treatment of the sample. 
The possibility to create a classified data set according to the specific weapon models, the nation of origin, and date of manufacturing of shrapnel balls, allowed us to obtain reliable results. The survey also provided interesting information on the chemical composition and the raw materials used during WWI.

The First World War munitions analysed were mainly made from $\mathrm{Pb}-\mathrm{Sb}$ alloys, $\mathrm{Fe}$ alloys and $\mathrm{Cu}$ alloys with variable concentrations of $\mathrm{Ni}$ and $\mathrm{Zn}$. The shrapnel ball samples consisted of soft $\mathrm{Pb}$ or $\mathrm{Pb}$ hardened with $\mathrm{Sb}$ depending on the use, the weapon type and the specific nation. The Italian shrapnel balls were made from hard $\mathrm{Pb}$ unlike the Austrian-Hungarian samples. Moreover, the Austrian-Hungarian shrapnel balls had a homogeneous chemical composition. Most of the Italian shrapnel balls dating back to 1875 had a different composition compared to other Italian samples and Austrian-Hungarian shrapnel balls.

Lead isotope analysis allowed a separation between Italian samples from 1875 for $75 \mathrm{~mm}$ and $120 \mathrm{~mm}$ calibre. Italian shrapnel balls dating back to 1900 (calibre $75 \mathrm{~mm}$ ) and 1917 (calibre $105 \mathrm{~mm}$ ) also had distinct lead isotope compositions. The Austrian-Hungarian shrapnel balls show a narrow range of variation of lead isotope ratios. The 1900 Austrian-Hungarian shrapnel balls (75 mm calibre) and 1917 (100 $\mathrm{mm}$ calibre) probably had the same $\mathrm{Pb}$ source. However, the use of recycled material for ammunition production changed the natural variation of isotope abundance ratios. Recycled material was probably used for the production of some Italian shrapnel balls. For this reason, the characterisation of samples of unknown origin (of the Marmolada Glacier and Trentino Alto Adige) can be difficult in some cases. Both analytical methods used showed a clear discrimination of the external jacket of the analysed bullets, which represented the most important part of a bullet, in relation to projectile type and specific nation. The bullet cores consisted of $\mathrm{Pb}-\mathrm{Sb}$ alloy regardless of the region of origin. This could indicate the use of preferably recycled material for the bullet cores.

This work allowed us to investigate for the first time along the Alpine front the potential applications of trace elements and lead isotope analyses to differentiate between military artefacts of different origins. This could largely benefit future reconstruction of WWI military fighting making it possible to determine the effective role played in the battle by each combatant force and the correspondence between literature and field data on the real deployment of soldiers

\section{Acknowledgements}

The authors thank the Italian War History Museum of Rovereto (Trento, Italy) and Marcuzzo Bruno for providing the samples and historical information. The authors would also like to thank Elga Water for the supply of the PureLab Option and Ultra pure water systems. 


\begin{tabular}{|c|c|c|c|c|c|c|c|c|c|c|c|c|c|c|c|c|c|c|c|c|c|c|c|}
\hline 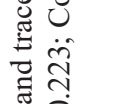 & تَ & $\begin{array}{l}\overrightarrow{0} \\
0\end{array}$ & & 1 & ' & \begin{tabular}{l}
$\infty$ \\
\multirow{+}{0}{} \\
0
\end{tabular} & $\dot{s}$ & 吕 & $\overline{\vec{i}}$ & $\stackrel{\infty}{\infty}$ & 吉 & ○. & $\begin{array}{l}\infty \\
\infty \\
-\end{array}$ & $\stackrel{n}{n}$ & $\stackrel{?}{\stackrel{\sim}{-}}$ & $\stackrel{\text { I }}{-}$ & $\stackrel{\overbrace{}}{\bumpeq}$ & $\stackrel{\text { ๓ి}}{-}$ & $\stackrel{n}{-}$ & $\stackrel{\Re}{\cong}$ & $\stackrel{m}{-}$ & $\begin{array}{l}0 \\
0 \\
0\end{array}$ & $\begin{array}{l}0 \\
0 \\
0\end{array}$ \\
\hline 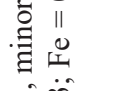 & సี & $\begin{array}{l}5 \\
0 \\
0\end{array}$ & $\begin{array}{l}0 \\
0 \\
0\end{array}$ & $\begin{array}{l}\infty \\
0 \\
0 \\
0\end{array}$ & 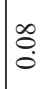 & $\frac{9}{0}$ & $\frac{9}{0}$ & $\tilde{n}$ & $\begin{array}{l}0 \\
0 \\
0 \\
0\end{array}$ & 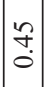 & 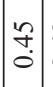 & $\begin{array}{l}\stackrel{q}{+} \\
\dot{0}\end{array}$ & \begin{tabular}{l}
8 \\
\hdashline \\
0
\end{tabular} & 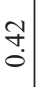 & $\begin{array}{l}0 \\
= \\
=\end{array}$ & $\begin{array}{c}n \\
0 \\
0\end{array}$ & กิ? & $\begin{array}{l}0 \\
\tilde{n} \\
0 \\
0\end{array}$ & $\begin{array}{l}\text { I. } \\
0\end{array}$ & 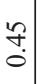 & $\stackrel{\varpi}{\tilde{o}}$ & $\begin{array}{l}0 \\
\vdots \\
0\end{array}$ & $\stackrel{\circ}{\circ}$ \\
\hline 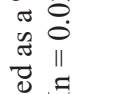 & $\exists$ 巳 & $\frac{9}{0}$ & $\begin{array}{l}\dot{0} \\
\dot{0} \\
\end{array}$ & $\begin{array}{l} \pm \\
0\end{array}$ & 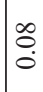 & $\hat{n}$ & 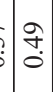 & 苟 & $\frac{n}{0}$ & $\stackrel{\nexists}{\square}$ & $\begin{array}{l} \pm \\
\\
0\end{array}$ & $\stackrel{n}{0}$ & $\stackrel{5}{\circ}$ & $\frac{\mathrm{I}}{\stackrel{0}{0}}$ & $\frac{1}{0}$ & $\mid \begin{array}{l}0 \\
\vdots \\
0\end{array}$ & $\stackrel{0}{\circ}$ & $\frac{9}{0}$ & $\begin{array}{c}0 \\
\stackrel{0}{0} \\
0\end{array}$ & $\frac{O}{0}$ & $\frac{1}{0}$ & $\frac{m}{0}$ & $\stackrel{2}{0}$ \\
\hline$\stackrel{\infty}{\infty}$ & $\bar{z}$ 巳 & సે. & ڤñ & 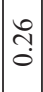 & $\stackrel{2}{n}$ & $\vec{f}$ & $\dot{8}$ & $\stackrel{\tilde{m}}{0}$ & $\begin{array}{l}\dot{0} \\
\dot{0}\end{array}$ & $\begin{array}{l}0 \\
0 \\
0\end{array}$ & $\begin{array}{l}0 \\
0 \\
\dot{0}\end{array}$ & $\hat{0}$ & \begin{tabular}{l}
0 \\
\hdashline \\
\end{tabular} & $\begin{array}{l}\stackrel{0}{\circ} \\
\stackrel{0}{\circ}\end{array}$ & $\begin{array}{l} \pm \\
0 \\
\end{array}$ & $\begin{array}{l} \pm \\
0 \\
\dot{0}\end{array}$ & $\stackrel{0}{0}$ & $\begin{array}{l}8 \\
\vdots \\
0\end{array}$ & \begin{tabular}{|c}
0 \\
0 \\
0
\end{tabular} & ¿. & $\frac{0}{0}$ & ָे. & $\tilde{\infty}$ \\
\hline 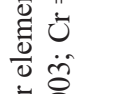 & 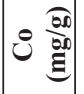 & $\dot{\vec{c}}$ & 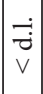 & $\begin{array}{l}\dot{C} \dot{\vec{c}} \\
\mathrm{v}\end{array}$ & ż & $\begin{array}{l}\dot{z} \\
\bar{v}\end{array}$ & $\begin{array}{l}\dot{\vec{r}} \\
\mathrm{v}\end{array}$ & $\begin{array}{l}\vec{i} \\
\vec{v}\end{array}$ & $\begin{array}{l}\dot{\vec{u}} \\
\mathrm{v}\end{array}$ & $\begin{array}{l}\dot{\vec{d}} \\
\mathrm{v}\end{array}$ & $\begin{array}{l}-\dot{Z} \\
\vec{v} \\
v\end{array}$ & $\overrightarrow{\dot{\vec{v}}}$ & $\begin{array}{l}\dot{\vec{c}} \\
\mathrm{v}\end{array}$ & $\overrightarrow{\vec{c}} \bar{v}$ & $\overrightarrow{\vec{\nabla}}$ & $\begin{array}{c}\dot{\vec{u}} \\
\mathrm{v}\end{array}$ & 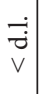 & $\begin{array}{l}\dot{\vec{j}} \\
\vec{v}\end{array}$ & 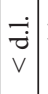 & 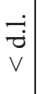 & $\begin{array}{l}\dot{\vec{z}} \\
\mathrm{v}\end{array}$ & $\begin{array}{l}\dot{\vec{r}} \\
\mathrm{v}\end{array}$ & $\begin{array}{l}\dot{z} \\
\dot{\sigma} \\
v\end{array}$ \\
\hline I & 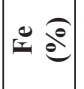 & $\begin{array}{l}\dot{\partial} \\
\vee\end{array}$ & V & v & Vं & $\dot{\vec{j}}$ & 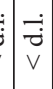 & $\overrightarrow{\vec{D}}$ & $\overrightarrow{\overrightarrow{\dot{v}}}$ & $\vec{i}$ & $\begin{array}{l}\overrightarrow{\dot{C}} \\
\mathrm{~g} \\
\mathrm{v}\end{array}$ & 它 & $\begin{array}{l}\dot{Z} \\
\vee \\
v\end{array}$ & $\begin{array}{l}\dot{\vec{c}} \\
\mathrm{v}\end{array}$ & $\begin{array}{l}\dot{i} \\
\dot{v} \\
v\end{array}$ & $\mid$ & $\begin{array}{l}\dot{c} \\
\dot{\vec{v}}\end{array}$ & $\mid \begin{array}{l}\forall \\
0 \\
\dot{0} \\
\sigma\end{array}$ & $\begin{array}{l}= \\
\dot{2} \\
a\end{array}$ & $\begin{array}{l}2 \\
\infty \\
2 \\
2\end{array}$ & $\begin{array}{l}\infty \\
\infty \\
\infty\end{array}$ & $\begin{array}{l}\dot{\vec{j}} \\
\mathrm{v}\end{array}$ & $\begin{array}{l}\vec{\partial} \\
\mathrm{v}\end{array}$ \\
\hline 4 & 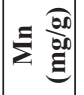 & $\begin{array}{l}n \\
n \\
0\end{array}$ & 文 & 占 & 年 & $\mid \begin{array}{l}\infty \\
0 \\
0\end{array}$ & $\begin{array}{l}\infty \\
\infty \\
0 \\
0 \\
0\end{array}$ & $\vec{\infty}$ & $\begin{array}{l}\dot{\vec{j}} \\
\mathrm{v}\end{array}$ & $\begin{array}{l}\dot{\vec{j}} \\
\mathrm{v}\end{array}$ & $\begin{array}{l}\dot{Z} \\
\dot{\vec{c}} \\
\mathrm{v}\end{array}$ & $\begin{array}{l}\dot{\vec{j}} \\
\mathrm{v}\end{array}$ & $\begin{array}{l}\dot{\vec{c}} \\
\mathrm{v}\end{array}$ & 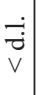 & $\begin{array}{l}\vec{\partial} \\
\mathrm{v}\end{array}$ & $\begin{array}{l}\dot{\vec{u}} \\
\mathrm{v}\end{array}$ & $\begin{array}{l}\dot{\vec{z}} \\
\mathrm{v}\end{array}$ & $\begin{array}{l}\dot{\vec{c}} \\
\mathrm{v}\end{array}$ & 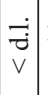 & 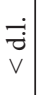 & $\begin{array}{l}\dot{\vec{z}} \\
\mathrm{v}\end{array}$ & $\begin{array}{l}0 \\
\vdots \\
0\end{array}$ & กิ \\
\hline 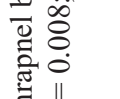 & ن & $\stackrel{\sim}{\stackrel{\sim}{i}}$ & $\infty$ & 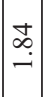 & $\stackrel{0}{2}$ & 竎 & 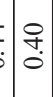 & $\hat{m}$ & $\mid \begin{array}{l}0 \\
0 \\
0 \\
0\end{array}$ & $\begin{array}{c}\bar{\infty} \\
0 \\
0\end{array}$ & $\stackrel{2}{2}$ & $\mid \begin{array}{c}\infty \\
\infty \\
0\end{array}$ & $\bar{\sigma}$ & 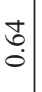 & $\begin{array}{l}\mathbf{6} \\
0 \\
0\end{array}$ & $\left|\begin{array}{l}\sigma \\
0 \\
0 \\
0\end{array}\right|$ & $\begin{array}{l}\stackrel{8}{0} \\
\dot{0}\end{array}$ & $\left|\begin{array}{c}n \\
\infty \\
0 \\
0\end{array}\right|$ & $\exists$ & $\stackrel{ \pm}{ \pm}$ & $\begin{array}{c}\infty \\
\infty \\
\dot{0}\end{array}$ & $\begin{array}{l}\dot{\vec{c}} \\
\mathrm{v}\end{array}$ & v \\
\hline 4 & $>\begin{array}{l}\frac{\partial 0}{600} \\
\Xi \\
\Xi\end{array}$ & $\begin{array}{l}7 \\
0 \\
0\end{array}$ & $\begin{array}{l}\infty \\
n \\
0 \\
0\end{array}$ & m. & ? & 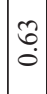 & $\begin{array}{l}0 \\
\vdots \\
\vdots \\
\vdots \\
0\end{array}$ & ñ & ?n & 守. & 守 & $\begin{array}{l}n \\
\mathfrak{o}\end{array}$ & 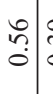 & ๗ે. & 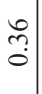 & $\mid \begin{array}{c}0 \\
\tilde{n} \\
0\end{array}$ & $\hat{0}$ & $\underline{n}$ & $\stackrel{n}{-}$ & 于. & $\stackrel{ \pm}{0}$ & $\begin{array}{l}\dot{\partial} \\
\vec{v} \\
v\end{array}$ & $\begin{array}{l}\vec{c} \\
\mathrm{v}\end{array}$ \\
\hline. & $=\begin{array}{l}\frac{800}{300} \\
\underline{\Xi}\end{array}$ & $\ddot{0}$ & $\ddot{0}$ & $\tilde{0}$ & $\tilde{0}$ & $\underset{-}{f}$ & $\dot{n}$ & 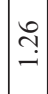 & $\stackrel{n}{n}$ & $\stackrel{\text { ঙิ }}{-}$ & $\stackrel{\overbrace{}}{\sim}$ & $\stackrel{n}{m}$ & $\stackrel{\overbrace{}}{-}$ & - & $\begin{array}{l}\dot{O} \\
\dot{0}\end{array}$ & à & $\stackrel{2}{0}$ & $\stackrel{2}{2}$ & $\vec{\sim}$ & $\stackrel{\infty}{n}$ & $\vec{a}$ & 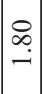 & 움. \\
\hline 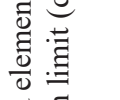 & $=\frac{800}{00}$ & ' & 1 & $i$ & ' & $\begin{array}{l}0 \\
\stackrel{0}{2} \\
\end{array}$ & $\stackrel{\sigma}{\sigma}$ & $\stackrel{\overbrace{}}{\stackrel{-}{-}}$ & 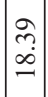 & $\left|\begin{array}{l}\infty \\
m \\
m \\
\sim\end{array}\right|$ & $\begin{array}{l}\vec{\sigma} \\
\dot{r}\end{array}$ & $\mid \begin{array}{l}n \\
0 \\
n \\
-\end{array}$ & $\begin{array}{l}\mathscr{2} \\
\dot{ \pm} \\
-\end{array}$ & $\begin{array}{l}\infty \\
n \\
\end{array}$ & $\begin{array}{l}\hat{b} \\
\dot{0}\end{array}$ & 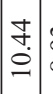 & $\hat{\infty}$ & $\begin{array}{l}n \\
\stackrel{n}{2} \\
=\end{array}$ & $\begin{array}{l}\stackrel{2}{2} \\
\stackrel{2}{-}\end{array}$ & ๗ે & $\tilde{n}$ & $\begin{array}{l}\dot{\vec{j}} \\
\mathrm{v}\end{array}$ & $\begin{array}{l}\dot{z} \\
\bar{z} \\
v\end{array}$ \\
\hline 。 & 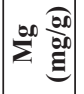 & $\begin{array}{l}\partial \\
\dot{\partial} \\
\dot{i}\end{array}$ & $\stackrel{\Re}{=}$ & $\stackrel{\Omega}{\Omega}$ & i̊ & 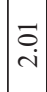 & 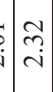 & $\stackrel{2}{2}$ & 年 & 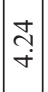 & $\begin{array}{c}\simeq \\
\dot{v}\end{array}$ & $\underset{\sim}{\tilde{\sigma}}$ & 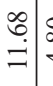 & 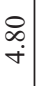 & $\begin{array}{l}\hat{b} \\
\stackrel{i}{i}\end{array}$ & $\begin{array}{l}N \\
\dot{N}\end{array}$ & $\frac{\vec{z}}{\dot{r}}$ & 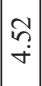 & 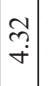 & $\stackrel{m}{\rightarrow}$ & $\begin{array}{l}\infty \\
n \\
n \\
n\end{array} \mid$ & 它 & $\stackrel{ \pm}{i}$ \\
\hline 吾 & 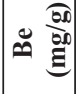 & $\stackrel{\square}{=}$ & da & à. & ڤ̊ & $\vec{n}$ & 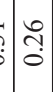 & 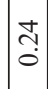 & $\begin{array}{l}n \\
\vdots \\
0\end{array}$ & $\hat{0}$ & $\ddot{0}$ & $\begin{array}{l}\infty \\
0 \\
0\end{array}$ & $\begin{array}{l}2 \\
0 \\
0\end{array}$ & \begin{tabular}{l} 
?̊. \\
\hdashline \\
0
\end{tabular} & ñ & 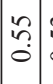 & $\stackrel{n}{n}$ & 守. & 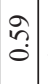 & 古 & ก̂. & $\overrightarrow{\overrightarrow{\vec{v}}}$ & $\overrightarrow{\dot{z}}$ \\
\hline $\begin{array}{ll}\vec{E} & \infty \\
0 & 0\end{array}$ & ב & $\begin{array}{l} \pm \\
0 \\
0\end{array}$ & $\begin{array}{l}0 \\
0 \\
0 \\
0\end{array}$ & $\begin{array}{l}0 \\
0 \\
0\end{array}$ & 1 & $\begin{array}{l}\infty \\
\dot{0}\end{array}$ & $\frac{m}{0}$ & $\frac{1}{0}$ & $\begin{array}{l}2 \\
0 \\
0\end{array}$ & $\begin{array}{l}n \\
\vdots \\
0\end{array}$ & $\frac{n}{0}$ & $\begin{array}{c}+ \\
\infty \\
\dot{0}\end{array}$ & \begin{tabular}{c|c}
$\infty$ & \\
$\infty$ & \\
0 &
\end{tabular} & $\begin{array}{l}\infty \\
n \\
0\end{array}$ & 吕 & ח & $\tilde{n}$ & $\mid$\begin{tabular}{l}
$n$ \\
\hdashline \\
0
\end{tabular} & $\begin{array}{l}3 \\
0 \\
0\end{array}$ & $\begin{array}{l}\infty \\
n \\
0\end{array}$ & 苟 & \pm & $\stackrel{2}{0}$ \\
\hline 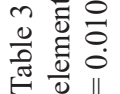 & 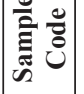 & -1 & $m$ & $\nabla$ & in & $\simeq$ & 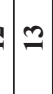 & \pm & $\because$ & 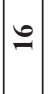 & $\Xi$ & $\infty$ & 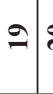 & 리 & $\bar{\sim}$ & สิ & $\ddot{\sim}$ & $\mathbf{N}$ & $\stackrel{2}{2}$ & 니 & 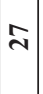 & $\bar{n}$ & हn \\
\hline
\end{tabular}




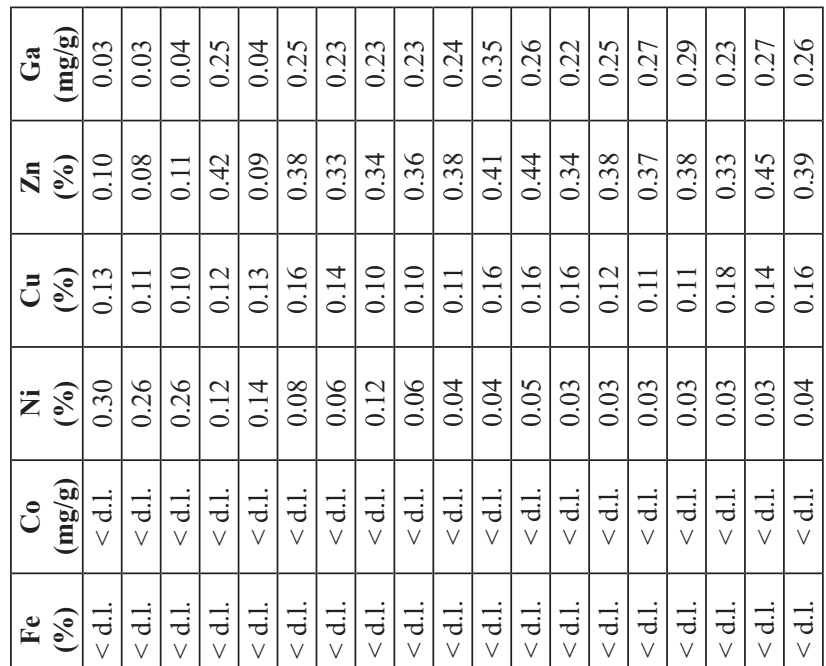

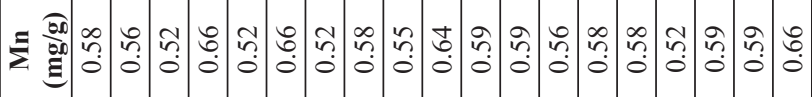

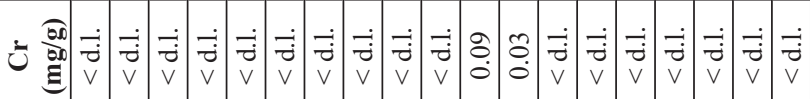

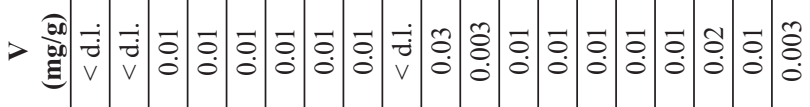

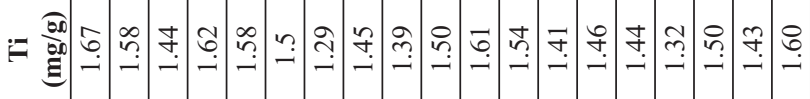

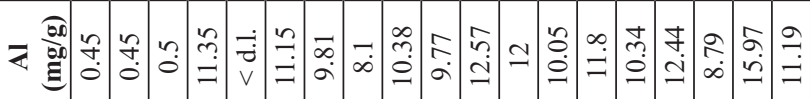

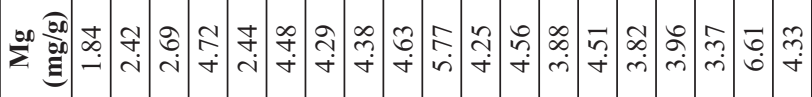

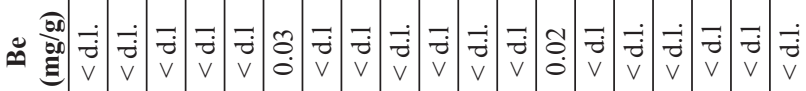




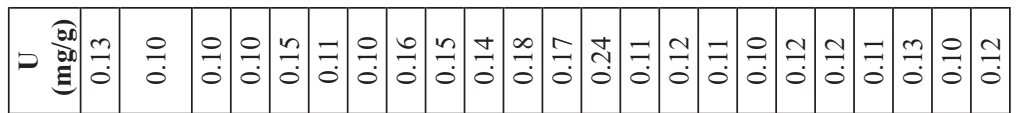

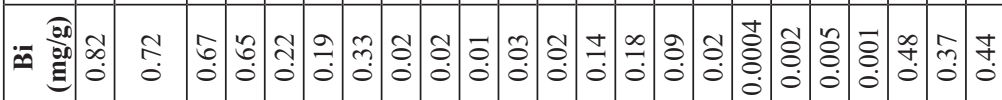
से

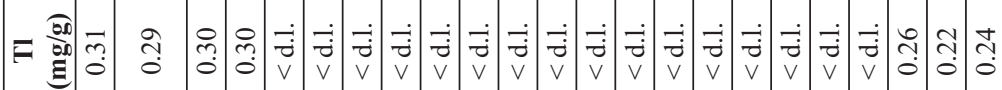

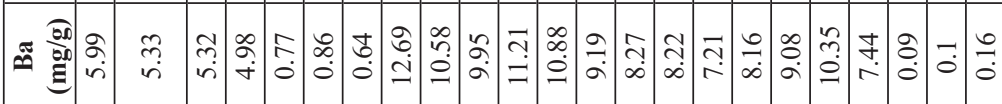

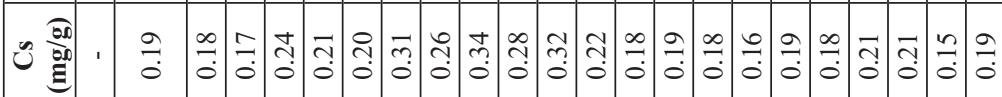
च

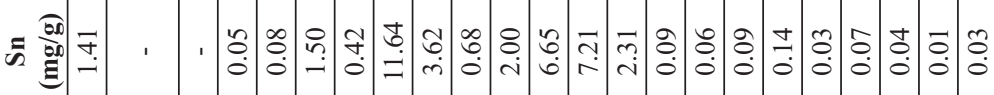

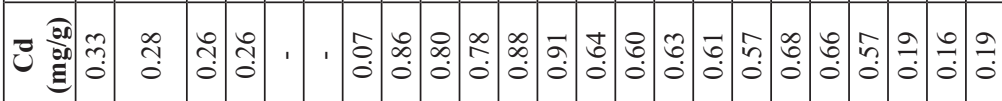

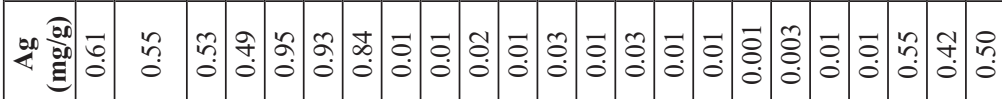

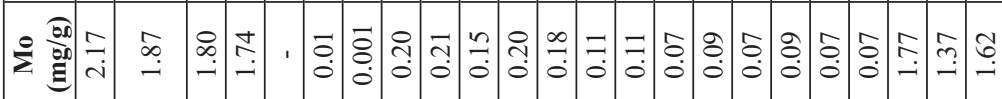

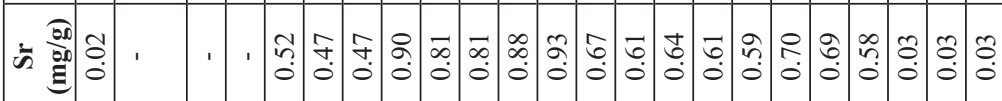

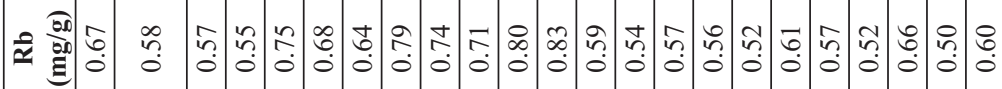

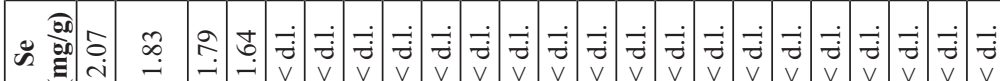

\begin{tabular}{|c|c|c|c|c|c|c|c|c|c|c|c|c|c|c|c|c|c|c|c|c|c|}
\hline $\begin{array}{l}\overrightarrow{000} \\
\stackrel{000}{3} \\
\equiv\end{array}$ & ભેฺ & $\underset{m}{m}$ & ָे & $\begin{array}{c}\partial \\
\text { iे }\end{array} \mid$ & $\hat{\tilde{u}}$ & $\begin{array}{l}\stackrel{a}{d} \\
\stackrel{d}{c}\end{array}$ & $\begin{array}{l}n \\
\mathfrak{b} \\
\dot{n}\end{array}$ & $\begin{array}{lll} & \\
0 & \\
i & \end{array}$ & $\stackrel{\hat{\sigma}}{-}$ & | & 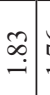 & 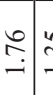 & 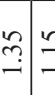 & $\because$ & $\begin{array}{c}0 \\
\dot{v} \\
\dot{v}\end{array}$ & $\stackrel{\text { f }}{\sim}$ & 으. & So & $\stackrel{\infty}{n}$ & $\begin{array}{lll}\vec{n} \\
i\end{array}$ & $\begin{array}{c}c \\
\text { con } \\
\text { in }\end{array}$ \\
\hline 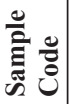 & -1 & $m$ & $\nabla$ & in & $\simeq$ & $\cong$ & \pm & $\because$ & 으 & ㄱ. & $\infty$ & 2 & 그 & $\vec{\nabla} \approx$ & $\vec{v} \mid \ddot{\sim}$ & $\stackrel{ \pm}{N}$ & 2 & i & 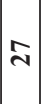 & $\bar{n}$ & กิ \\
\hline
\end{tabular}




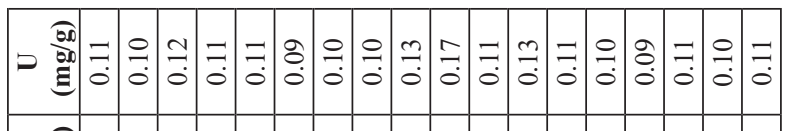

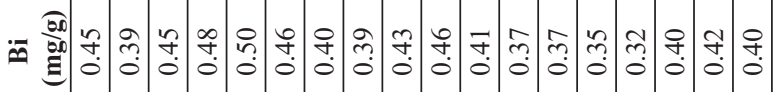

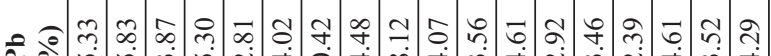

है

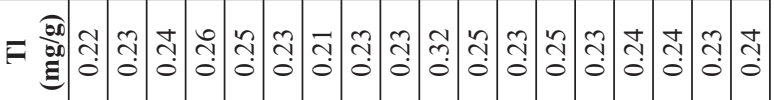

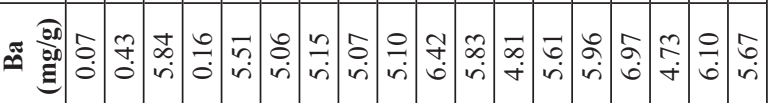

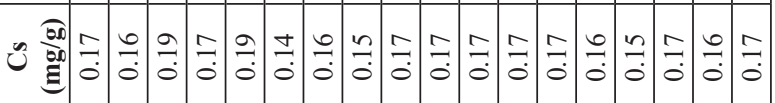

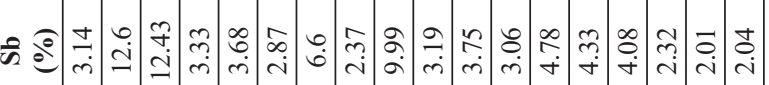

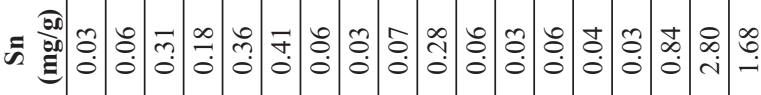

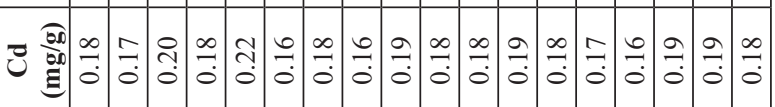

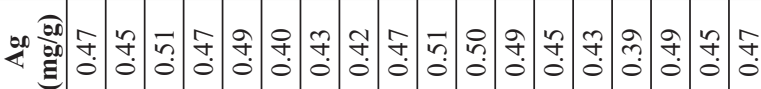

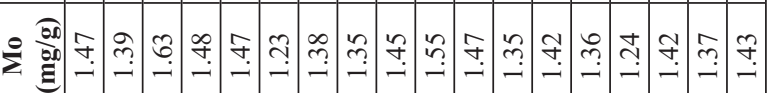

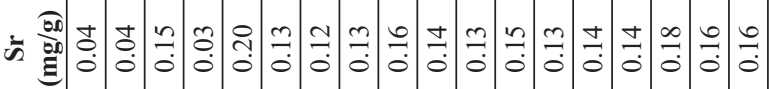

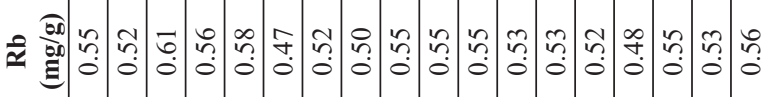

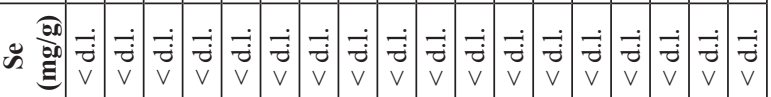

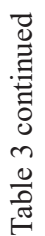

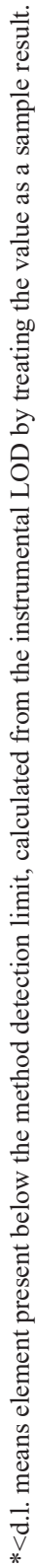




\begin{tabular}{|c|c|c|c|c|c|c|c|c|c|c|c|c|c|c|c|c|c|c|c|c|c|c|c|c|}
\hline$\ddot{\infty}$ & ت & \begin{tabular}{l}
$\infty$ \\
\hdashline \\
-
\end{tabular} & ले & $\stackrel{\infty}{=}$ & $\stackrel{\substack{* \\
\hdashline}}{-}$ & ले & 을 & $\stackrel{\substack{0 \\
-i}}{-}$ & $\stackrel{\infty}{\stackrel{\infty}{\sim}}$ & $\stackrel{m}{-}$ & $\tilde{n}$ & $\stackrel{\sim}{\sim}$ & $\begin{array}{l} \pm \\
0 \\
0\end{array}$ & $\begin{array}{l} \pm \\
0 \\
0\end{array}$ & $\begin{array}{l}0 \\
0 \\
0\end{array}$ & $\begin{array}{l} \pm \\
\dot{0} \\
0\end{array}$ & $\begin{array}{c}3 \\
0 \\
0\end{array}$ & $\mid \begin{array}{l}n \\
0 \\
0\end{array}$ & $\stackrel{ \pm}{ \pm}$ & $\left|\begin{array}{l}\infty \\
0 \\
0 \\
0\end{array}\right|$ & $\bar{n}$ & $\tilde{n}$ & $\mid \begin{array}{l}\infty \\
0 \\
0 \\
0\end{array}$ & ? \\
\hline$\stackrel{\infty}{=}$ & సี & $\tilde{n}$ & ?ֶ. & ?ె. & 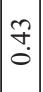 & ले & 过 & 文 & $\hat{n}$ & స్. & fं & $\begin{array}{l}m \\
\tilde{n} \\
0\end{array}$ & $\begin{array}{c}0 \\
0 \\
0\end{array}$ & $\frac{m}{0}$ & $\frac{n}{a}$ & 官 & m. & $\mid \begin{array}{l}0 \\
n \\
0 \\
0\end{array}$ & $\stackrel{\sim}{\sim}$ & : & 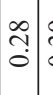 & लें & 帒 & ले \\
\hline 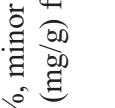 & है & $\mid \begin{array}{c}0 \\
\dot{0}\end{array}$ & $\begin{array}{c}0 \\
0 \\
0\end{array}$ & $\mid \begin{array}{l}0 \\
\dot{0}\end{array}$ & 苗 & $\hat{a}$ & 号 & în & $\stackrel{1}{\stackrel{1}{0}}$ & $\mid \begin{array}{c}0 \\
0 \\
0\end{array}$ & 志 & $\begin{array}{c}0 \\
0 \\
0\end{array}$ & $\frac{m}{0}$ & $\frac{n}{0}$ & సָ̣ & 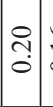 & \begin{tabular}{c}
0 \\
\hdashline \\
0
\end{tabular} & \begin{tabular}{l}
0 \\
\hdashline \\
0
\end{tabular} & $\begin{array}{l}\hat{\alpha} \\
\dot{n} \\
\infty\end{array}$ & $\begin{array}{l}\vec{n} \\
i \\
0 \\
0\end{array}$ & $\begin{array}{l}\stackrel{2}{*} \\
\dot{\alpha}\end{array}$ & 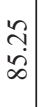 & $\begin{array}{c}n \\
\tilde{n} \\
\infty \\
\infty\end{array}$ & $\stackrel{2}{i}$ \\
\hline$\stackrel{=}{=} \stackrel{0}{\circ}$ & $\bar{z}$ ê & $\begin{array}{l}0 \\
0 \\
0\end{array}$ & $\begin{array}{l} \pm \\
0 \\
0\end{array}$ & $\mid \begin{array}{l}0 \\
0 \\
0\end{array}$ & $\stackrel{\infty}{\dot{0}}$ & $\frac{\infty}{0}$ & $\stackrel{1}{\stackrel{1}{0}}$ & $\mid \begin{array}{l}n \\
0 \\
0\end{array}$ & $\begin{array}{l}0 \\
0 \\
0\end{array}$ & $\mid \begin{array}{l}0 \\
0 \\
0\end{array}$ & $\begin{array}{l}0 \\
0 \\
0\end{array}$ & $\begin{array}{l}0 \\
0 \\
0\end{array}$ & 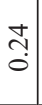 & $\stackrel{2}{2}$ & 吉 & $\tilde{n}$ & 잉 & $\mid \begin{array}{l}\infty \\
0 \\
0 \\
0\end{array}$ & $\begin{array}{l}\hat{f} \\
\dot{ \pm}\end{array}$ & $\mid \begin{array}{l}2 \\
2 \\
\Sigma\end{array}$ & $=$ & $\begin{array}{l} \pm \\
\pm \\
\pm\end{array}$ & $\begin{array}{l}\hat{\partial} \\
\dot{J}\end{array}$ & 文 \\
\hline 尊 & ن & 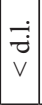 & $\begin{array}{l}\dot{\vec{j}} \\
\mathrm{v}\end{array}$ & 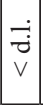 & $\mid \begin{array}{l}\dot{\vec{j}} \\
\mathrm{v}\end{array}$ & चj & $\begin{array}{l}\dot{\vec{u}} \\
\overrightarrow{\vec{v}}\end{array}$ & $\begin{array}{l}\dot{\vec{u}} \\
\mathrm{v}\end{array}$ & $\begin{array}{l}\dot{\vec{c}} \\
\overrightarrow{\vec{v}}\end{array}$ & $\mid \begin{array}{l}\dot{\vec{z}} \\
\mathrm{v}\end{array}$ & $\mid \begin{array}{l}\dot{Z} \\
\vec{\nabla} \\
\mathrm{v}\end{array}$ & $\dot{\overrightarrow{\dot{u}}}=$ & $\overrightarrow{\vec{\nabla}}$ & $\begin{array}{l}\dot{\vec{j}} \\
\mathrm{v}\end{array}$ & 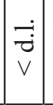 & 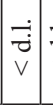 & $\begin{array}{l}\dot{\vec{z}} \\
\mathrm{v}\end{array}$ & $\begin{array}{l}\dot{\vec{c}} \\
\mathrm{v}\end{array}$ & $\stackrel{1}{0}$ & $\left|\begin{array}{l}0 \\
0 \\
0\end{array}\right|$ & $\stackrel{\infty}{\stackrel{\infty}{\sim}}$ & $\stackrel{+}{\circ}$ & $\tilde{n}$ & V \\
\hline $\begin{array}{ll} & \\
0 & \| \\
& 0 \\
\end{array}$ & 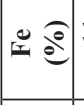 & $\mid \begin{array}{l}\dot{\vec{c}} \\
\mathrm{v} \\
\mathrm{v}\end{array}$ & $\begin{array}{l}\dot{\vec{c}} \\
\overrightarrow{\mathrm{v}} \\
\mathrm{v}\end{array}$ & $\begin{array}{l}\overrightarrow{\dot{\vec{j}}} \\
\mathrm{v}\end{array}$ & $\begin{array}{l}\dot{\vec{j}} \\
\mathrm{v} \\
\mathrm{v}\end{array}$ & च & $\begin{array}{l}\dot{z} \\
\vec{z} \\
v\end{array}$ & $\begin{array}{l}\overrightarrow{\dot{g}} \\
\mathrm{v}\end{array}$ & $\begin{array}{l}\dot{z} \\
\dot{\vec{c}} \\
\mathrm{v}\end{array}$ & $\begin{array}{l}\dot{\vec{g}} \\
\mathrm{v}\end{array}$ & $\begin{array}{l}\dot{Z} \\
\dot{z} \\
v\end{array}$ & $\begin{array}{l}\dot{\vec{u}} \\
\mathrm{v}\end{array}$ & $\begin{array}{l}\overrightarrow{\dot{z}} \\
\mathrm{v}\end{array}$ & $\begin{array}{l}\dot{i} \\
\dot{\vec{v}} \\
\mathrm{v}\end{array}$ & $\begin{array}{l}\dot{\vec{j}} \\
\mathrm{v}\end{array}$ & 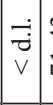 & 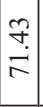 & $\begin{array}{l}0 \\
\hat{2} \\
i n\end{array}$ & $\begin{array}{l}-\dot{j} \\
\vec{z} \\
v\end{array}$ & $\mid \begin{array}{l}\dot{z} \\
\vec{\partial} \\
v\end{array}$ & $\begin{array}{l}\dot{\vec{\theta}} \\
\mathrm{v}\end{array}$ & $\begin{array}{l}\bar{c} \\
\vec{\partial} \\
v\end{array}$ & $\begin{array}{l}\overrightarrow{\dot{r}} \\
\mathrm{v}\end{array}$ & $\begin{array}{l}\vec{\sigma} \\
\bar{v}\end{array}$ \\
\hline$\hat{s}$ & 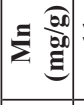 & $\begin{array}{l}\dot{i} \\
\dot{v} \\
v\end{array}$ & $\begin{array}{l}\dot{i} \\
\dot{\vec{j}} \\
\mathrm{v}\end{array}$ & $\begin{array}{l}\dot{\vec{j}} \\
\mathrm{v}\end{array}$ & $\begin{array}{l}\dot{i} \\
\overrightarrow{\dot{v}} \\
v\end{array}$ & ₹ & $\mid \begin{array}{l}\dot{\vec{j}} \\
\bar{v}\end{array}$ & $\begin{array}{l}\dot{\bar{c}} \\
\overline{\dot{\sigma}} \\
\mathrm{v}\end{array}$ & $\begin{array}{l}\dot{\vec{c}} \\
\bar{v} \\
\mathrm{v}\end{array}$ & $\begin{array}{l}\dot{\vec{r}} \\
\mathrm{v}\end{array}$ & $\begin{array}{l}\dot{z} \\
\vec{z} \\
v\end{array}$ & $\begin{array}{l}\dot{\vec{u}} \\
\mathrm{v}\end{array}$ & $\begin{array}{l}\vec{b} \\
\dot{0}\end{array}$ & $\hat{0}$ & $\ddot{\sigma}$ & : & $\begin{array}{l}\dot{\vec{j}} \\
\mathrm{v}\end{array}$ & $\begin{array}{l}\dot{\vec{c}} \\
\mathrm{v} \\
\mathrm{v}\end{array}$ & $\begin{array}{l}\dot{\vec{j}} \\
\mathrm{v}\end{array}$ & $\mid \begin{array}{l}\dot{Z} \\
\overrightarrow{\dot{z}} \\
\mathrm{v}\end{array}$ & $\begin{array}{l}\dot{\vec{c}} \\
\mathrm{v}\end{array}$ & $\begin{array}{l}\dot{\partial} \\
\bar{v} \\
v\end{array}$ & $\begin{array}{l}\overrightarrow{\vec{z}} \\
v\end{array}$ & v \\
\hline $\begin{array}{l}\tilde{0} \\
\stackrel{0}{0}\end{array}$ & 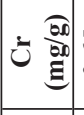 & $\mid \begin{array}{l}n \\
0 \\
0\end{array}$ & $\mid \begin{array}{l}3 \\
\dot{0} \\
\end{array}$ & $\begin{array}{l}n \\
\mathfrak{0} \\
0\end{array}$ & $\begin{array}{l}n \\
\vdots \\
0\end{array}$ & ?̊ & $\mid \begin{array}{l}0 \\
n \\
0 \\
0\end{array}$ & $\begin{array}{l}\stackrel{P}{2} \\
\dot{0}\end{array}$ & $\left|\begin{array}{l}n \\
0 \\
0 \\
0\end{array}\right|$ & $\mid \begin{array}{l}0 \\
n \\
0 \\
0\end{array}$ & ñ & ñ? & $\begin{array}{l}\vec{\nabla} \\
v\end{array}$ & $\begin{array}{l}\dot{\vec{d}} \\
\mathrm{v}\end{array}$ & $\begin{array}{l}\dot{\vec{j}} \\
\mathrm{v}\end{array}$ & $\begin{array}{l}\dot{j} \\
\overrightarrow{\dot{j}} \\
\mathrm{v}\end{array}$ & 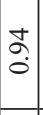 & $\stackrel{8}{8}$ & $\begin{array}{l}\infty \\
0 \\
0\end{array}$ & ふ઼ & $\stackrel{N}{\stackrel{1}{0}}$ & $\begin{array}{l}\stackrel{0}{\circ} \\
0\end{array}$ & ఏ. & $\begin{array}{l}\frac{0}{2} \\
\vdots\end{array}$ \\
\hline \pm & $>\begin{array}{l}\frac{\theta 00}{600} \\
\underline{E}\end{array}$ & ले & $\begin{array}{c}\infty \\
\cdots \\
0 \\
0\end{array}$ & $\begin{array}{l}3 \\
0\end{array}$ & $\begin{array}{l}n \\
\stackrel{n}{0} \\
\dot{0}\end{array}$ & mे & $\begin{array}{l}\tilde{n} \\
\tilde{0}\end{array}$ & $\begin{array}{l}\vec{\sigma} \\
\dot{0}\end{array}$ & $\dot{0}$ & $\begin{array}{c}\tilde{m} \\
\stackrel{0}{0}\end{array}$ & $\tilde{n}$ & $\begin{array}{l}0 \\
m \\
0 \\
0\end{array}$ & $\begin{array}{l}\overrightarrow{0} \\
\dot{0}\end{array}$ & $\overrightarrow{0}$ & $\begin{array}{l}0 \\
0 \\
0\end{array}$ & $\begin{array}{l}\overrightarrow{\vec{D}} \\
\mathrm{v}\end{array}$ & \begin{tabular}{l}
0 \\
\hdashline \\
0
\end{tabular} & $\begin{array}{l}0 \\
0 \\
0\end{array}$ & $\stackrel{ \pm}{\square}$ & $\left(\begin{array}{c}n \\
0 \\
0\end{array}\right.$ & $\stackrel{\sim}{\hdashline}$ & $\stackrel{\sim}{\stackrel{0}{0}}$ & $\begin{array}{l} \pm \\
\\
\end{array}$ & $\stackrel{m}{0}$ \\
\hline 5 & $=\frac{900}{600}$ & 하. & 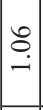 & $\begin{array}{c}\infty \\
\vdots \\
0\end{array}$ & $\stackrel{9}{-}$ & $\hat{\sigma}$ & 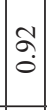 & $\hat{0}$ & $\underline{0}$ & $\tilde{\hat{o}}$ & $\mid \begin{array}{l}\infty \\
\dot{0}\end{array}$ & $\begin{array}{l}0 \\
0 \\
0\end{array}$ & $\underset{-}{\vec{b}}$ & $\stackrel{\Omega}{\sigma}$ & $\begin{array}{l}\vec{J} \\
\stackrel{i}{*}\end{array}$ & 吕 & $\begin{array}{l}0 \\
0 \\
0\end{array}$ & $\begin{array}{l}0 \\
0 \\
0\end{array}$ & $\begin{array}{c}0 \\
0 \\
0\end{array}$ & $\ddot{0}$ & $\begin{array}{l} \pm \\
0 \\
0\end{array}$ & $\begin{array}{l} \pm \\
0 \\
0\end{array}$ & $=$ & $\begin{array}{l}\sigma \\
0 \\
0\end{array}$ \\
\hline . & $<\frac{00}{000}$ & $\begin{array}{l}\infty \\
0 \\
0 \\
0\end{array}$ & $\begin{array}{l}n \\
a \\
a\end{array} \mid$ & 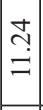 & $\begin{array}{l}\forall \\
\ddot{0}\end{array}$ & $\stackrel{\nabla}{\ddot{m}}$ & $\bar{m}$ & $\begin{array}{l}= \\
\sigma \\
-0\end{array}$ & $\begin{array}{l}\infty \\
\stackrel{\infty}{=} \\
=\end{array}$ & $\begin{array}{l}0 \\
\ddot{2}\end{array}$ & $\stackrel{\sim}{=}$ & $\mid \begin{array}{c}0 \\
\infty \\
0 \\
0\end{array}$ & $\begin{array}{l}\overrightarrow{\dot{\theta}} \\
\mathrm{v}\end{array}$ & $\begin{array}{l}\dot{i} \\
\vec{v} \\
v\end{array}$ & $\begin{array}{l}\dot{\vec{C}} \\
\overrightarrow{\mathrm{v}}\end{array}$ & $\begin{array}{c}\dot{i} \\
\overrightarrow{\dot{d}} \\
\mathrm{v}\end{array}$ & $\stackrel{n}{a}$ & $\begin{array}{l}n \\
n \\
\dot{ \pm}\end{array}$ & $\begin{array}{l}n \\
n \\
\infty\end{array}$ & $\left|\begin{array}{c}n \\
\infty \\
\\
-\end{array}\right|$ & 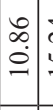 & 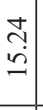 & $\begin{array}{l}2 \\
a \\
a\end{array}$ & $\begin{array}{l}\text { d } \\
\text { İ }\end{array}$ \\
\hline$\frac{\pi}{0}$ & 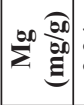 & mे & $\begin{array}{l}\circ \\
\text { m. } \\
\end{array}$ & స్̀ & $\stackrel{m}{\stackrel{9}{+}}$ & ક & $\begin{array}{l}+ \\
\text { ì }\end{array}$ & $\exists$ & $\begin{array}{l}\dot{g} \\
\dot{+}\end{array}$ & $\mid \begin{array}{l}\infty \\
\infty \\
\dot{\forall}\end{array}$ & $\begin{array}{l}0 \\
\dot{0} \\
\dot{r}\end{array}$ & $=$ & ñ & $\begin{array}{l}\stackrel{q}{+} \\
\dot{i}\end{array}$ & $\begin{array}{l}\infty \\
\dot{+} \\
\dot{r}\end{array}$ & $\stackrel{2}{-}$ & $\begin{array}{l}-\dot{j} \\
\vec{\partial} \\
v\end{array}$ & $\mid \begin{array}{l}\dot{j} \\
\dot{\vec{j}} \\
\mathrm{v}\end{array}$ & $\begin{array}{l}\dot{i} \\
\vec{\partial} \\
v\end{array}$ & $\mid \begin{array}{l}\dot{C} \\
\dot{\vec{c}} \\
\mathrm{v}\end{array}$ & ت்َ & $\begin{array}{l}\bar{\partial} \\
\vec{\partial} \\
v\end{array}$ & $\begin{array}{l}\dot{j} \\
\bar{v} \\
v\end{array}$ & चj \\
\hline 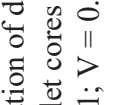 & 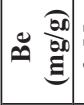 & $\mid \begin{array}{l}n \\
n \\
0 \\
0\end{array}$ & 苞 & $\begin{array}{l}+ \\
\dot{0} \\
0\end{array}$ & $\begin{array}{l}\vec{t} \\
\dot{0} \\
\dot{0}\end{array}$ & ج̊. & 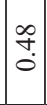 & $\hat{n}$ & ñ. & 守 & 年 & $\stackrel{\mathscr{f}}{\dot{\sigma}}$ & $\begin{array}{l}\overrightarrow{0} \\
\dot{0}\end{array}$ & $\begin{array}{l}\overrightarrow{\vec{j}} \\
\mathrm{v}\end{array}$ & $\overrightarrow{0}$ & $\begin{array}{l}1 \\
0 \\
0\end{array}$ & $\stackrel{+}{m}$ & $\begin{array}{l}n \\
\tilde{n} \\
0\end{array}$ & 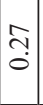 & $\begin{array}{l}m \\
\tilde{n} \\
0\end{array}$ & $\hat{\overbrace{}}$ & 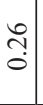 & $\stackrel{m}{0}$ & ह่ \\
\hline 8 & $=\frac{900}{900}$ & $\begin{array}{l}\infty \\
\infty \\
\vdots \\
0\end{array}$ & $\begin{array}{l}\infty \\
n \\
0 \\
0\end{array}$ & $\mid \begin{array}{l}0 \\
+ \\
0 \\
0\end{array}$ & $\begin{array}{l}6 \\
0 \\
0\end{array}$ & $\tilde{n}$ & $\mid \begin{array}{l}0 \\
0 \\
0\end{array}$ & $\begin{array}{l}\overrightarrow{0} \\
\dot{0}\end{array}$ & $\mid \begin{array}{l}\infty \\
n \\
0 \\
0\end{array}$ & 守 & 守 & $\begin{array}{l}0 \\
+ \\
0 \\
0\end{array}$ & $\frac{n}{0}$ & $\frac{1}{0}$ & ঙ્গి & $\begin{array}{l}0 \\
0 \\
0\end{array}$ & $\mid \begin{array}{l}\infty \\
0 \\
0 \\
0\end{array}$ & $\begin{array}{l} \pm \\
0 \\
0\end{array}$ & $\begin{array}{l}0 \\
\vdots \\
0\end{array}$ & $\left|\begin{array}{l}n \\
0 \\
0\end{array}\right|$ & $\stackrel{+}{0}$ & $\begin{array}{l}0 \\
0 \\
0\end{array}$ & $\begin{array}{l} \pm \\
0 \\
0\end{array}$ & $\begin{array}{l}2 \\
0 \\
0\end{array}$ \\
\hline 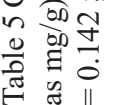 & 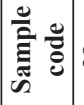 & ลิ & $\frac{\pi}{m}$ & लึ & లై & ले & బొ & 包 & 总 & ले & 突 & $\stackrel{\mathbb{J}}{\text { ป }}$ & $\frac{\pi}{7}$ & $\begin{array}{l}\infty \\
\infty \\
+\end{array}$ & 守 & ถึ่ & ิे & $\stackrel{0}{m}$ & लి & ले & ले & है & है & $\vec{\infty}$ \\
\hline
\end{tabular}




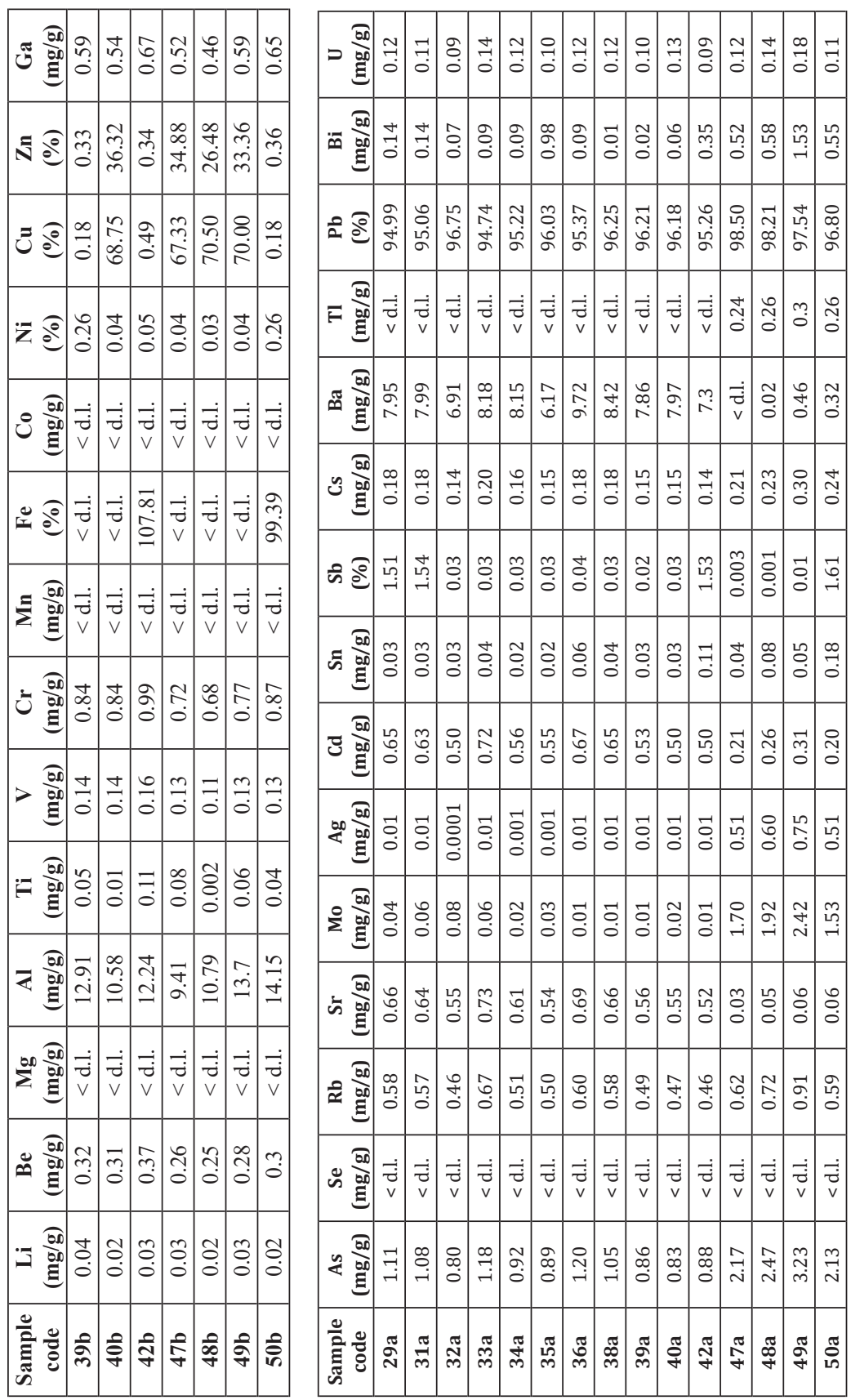




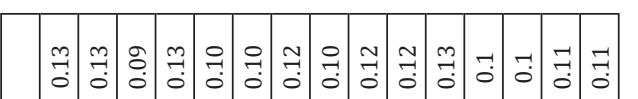

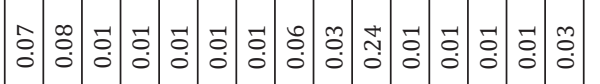

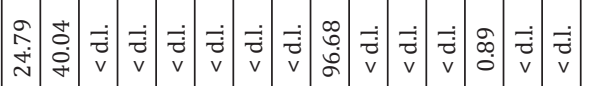

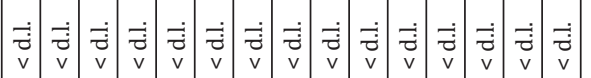

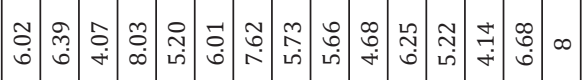

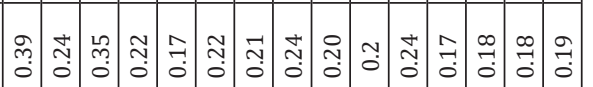

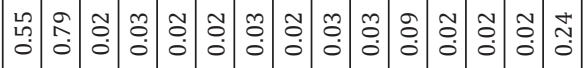

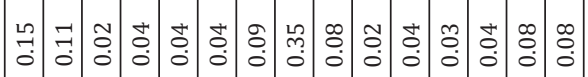

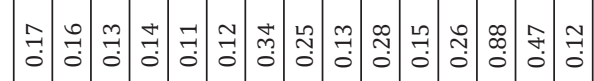

苞

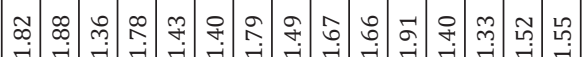

ᄀ.

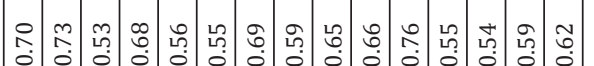

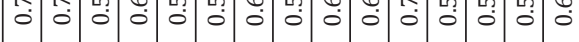

v $\begin{gathered}\vec{c} \\ \text { v }\end{gathered}$

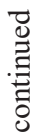

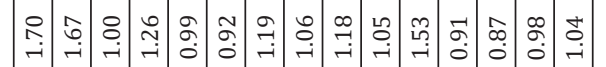

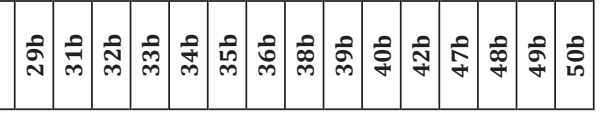

\begin{tabular}{|c|c|c|c|c|c|c|}
\hline & : & $\mid \begin{array}{l}0 \\
y \\
\text { i }\end{array}$ & 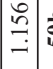 & ڤิ) & & 导 \\
\hline 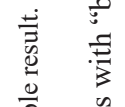 & $\frac{\pi}{\hat{\sigma}}$ & $\mid \begin{array}{c}\stackrel{\tilde{\vartheta}}{\vartheta} \\
\stackrel{\sim}{i}\end{array}$ & $\stackrel{i}{\stackrel{n}{=}}$ & $\vec{q}$ & 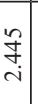 & $\stackrel{?}{\leftrightarrows}$ \\
\hline$\frac{\frac{\pi}{0}}{\frac{\pi}{2}}$ & 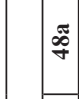 & 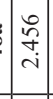 & $\stackrel{\substack{0 \\
:}}{=}$ & $\stackrel{0}{\stackrel{\infty}{+}}$ & 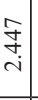 & 象 \\
\hline 可 & $\frac{\pi}{5}$ & 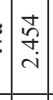 & 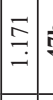 & 암 & $\begin{array}{l}\stackrel{a}{f} \\
\text { i }\end{array}$ & 象 \\
\hline$\stackrel{\overline{ \pm}}{\underline{0}}$ & $\underset{\mathcal{F}}{\mathcal{F}}$ & 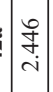 & $\stackrel{n}{\stackrel{2}{-}}$ & สิ & $\begin{array}{l}\tilde{b} \\
\stackrel{1}{+} \\
\text { i. }\end{array}$ & $\stackrel{n}{=}$ \\
\hline 3 & $\stackrel{\pi}{8}$ & $\mid \begin{array}{c}\infty \\
⿱ \\
⿱ \\
i \\
i\end{array}$ & $\stackrel{\tilde{n}}{\stackrel{-}{=}}$ & ثิ) & \begin{tabular}{l|l}
0 \\
$⿱$ \\
$\vdots$ \\
$i$
\end{tabular} & $\stackrel{8}{-}$ \\
\hline $\bar{\Xi}$ & ભ็ & $\mid \begin{array}{l}7 \\
⿱ \\
i \\
i\end{array}$ & $\stackrel{0}{=}$ & है & $\begin{array}{l}0 \\
⿱ \\
⿱ \\
i\end{array}$ & $\stackrel{n}{=}$ \\
\hline $\begin{array}{l}0 \\
0 \\
0 \\
0\end{array}$ & 心్ & $\mid \begin{array}{c}\stackrel{+}{\tilde{g}} \\
\stackrel{i}{i}\end{array}$ & $\stackrel{?}{\stackrel{g}{\Xi}}$ & 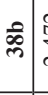 & $\begin{array}{l}\stackrel{N}{f} \\
\stackrel{i}{i}\end{array}$ & $\stackrel{\Omega}{\Xi}$ \\
\hline E & స్ల్ల & $\left|\begin{array}{c}n \\
\mathfrak{n} \\
i \\
\end{array}\right|$ & $\stackrel{0}{=}$ & : & 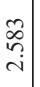 & $\stackrel{?}{=}$ \\
\hline 胥 & ల్లు & $\left|\begin{array}{c}\infty \\
\tilde{\vartheta} \\
\stackrel{i}{i}\end{array}\right|$ & 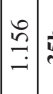 & कि: & $\begin{array}{l}\stackrel{7}{J} \\
i\end{array}$ & ? \\
\hline $\begin{array}{l}\vec{\Xi} \\
0 \\
0\end{array}$ & ঙु & $\mid \begin{array}{c}0 \\
⿱ \\
7 \\
i\end{array}$ & $\stackrel{n}{=}$ & ले & \begin{tabular}{l}
$\bar{n}$ \\
\multirow{5}{*}{} \\
$i$
\end{tabular} & $\stackrel{\infty}{?}$ \\
\hline $\begin{array}{l}0 \\
0 \\
0\end{array}$ & ల్ల & $\mid \begin{array}{l}\tilde{y} \\
\stackrel{i}{i}\end{array}$ & $\stackrel{+}{0}$ & ले & $\begin{array}{l}\text { ț } \\
\stackrel{5}{i} \\
\text { i }\end{array}$ & ت \\
\hline ষ্ & స్ లై & $\left|\begin{array}{l}q \\
⿱ 亠 䒑 \\
i\end{array}\right|$ & $\stackrel{\sim}{=}$ & సి & 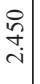 & $\underset{t}{+}$ \\
\hline $\begin{array}{l}\text { है } \\
\mathscr{2}\end{array}$ & Оิ & $\mid \begin{array}{c}\tilde{z} \\
\stackrel{f}{i} \\
\sim\end{array}$ & : & 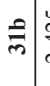 & $\begin{array}{c}\stackrel{2}{7} \\
\stackrel{i}{i}\end{array}$ & $\stackrel{n}{\ddagger}$ \\
\hline ت্ّু & 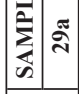 & $\begin{array}{l}\vec{J} \\
\stackrel{J}{i} \\
\end{array}$ & $\stackrel{\vec{n}}{=}$ & 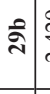 & 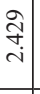 & $\underset{I}{\stackrel{g}{Z}}$ \\
\hline & & 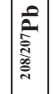 & 音 & & 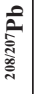 & 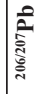 \\
\hline
\end{tabular}




\section{Endnotes}

${ }^{1}$ B Marcuzzo. Munizioni d'artiglieria italiana 1915-1918, volume II: Proietti. Pescara Editori, 2003.

${ }^{2}$ B Marcuzzo. "Shrapnel”. L'idea e l'evoluzione, il disuso e il reimpiego, nell'arco di due secoli. Editori Saisera, 2011.

${ }^{3}$ Ibid.

${ }^{4}$ Italian Law No. 78/2001. "Tutela del patrimonio storico della Prima guerra mondiale". Gazzetta Ufficiale 75. 30 March 2001.

${ }^{5}$ L Long. "Lead isotopes". In: CP Marshall \& RW Fairbridge (eds), Encyclopedia of Geochemistry. Dordrecht: Kluwer Academic, 1999.

${ }^{6}$ AP Dickin. Radiogenic isotope geology. Cambridge: Cambridge University Press, 2005.

${ }^{7}$ WV Ault, RG Senechal \& WE Erlebach. "Isotopic composition as a natural tracer of lead in the environment". Environ. Sci. Tech 4. 1970. 305-313.

${ }^{8} \mathrm{~L}$ Balcaen, L Moens \& F Vanhaecke. "Determination of isotope ratios of metals (and metalloids) by means of inductively coupled plasma-mass spectrometry for provenancing purposes: A review". Spectrochimica Acta Part B 65. 2010. 769-786; S Baron, C Le-Carlier, J Carignan \& A Ploquin. "Archaeological reconstruction of medieval lead production: Implications for ancient metal provenance studies and paleopollution tracing by $\mathrm{Pb}$ isotopes". Applied Geochemistry 24/11. 2009. 2093-2101; I Kuleff, I Iliev, E Pernicka \& D Gergova. "Chemical and lead isotope compositions of lead artefacts from ancient Thracia (Bulgaria)". Journal of Cultural Heritage 7. 2006. 244-256.

${ }^{9} \mathrm{GW}$ Stupian. "Lead isotope ratio measurements: A potential method for bullet identification". Journal of the Forensic Science Society 15. 1975. 161-164; GW Stupian, NA Ives, N Marquez \& BA Morgan. "The application of lead isotope analysis to bullet individualization in two homicides". Journal of the Forensic Sciences 46/6. 2001. 1342-1351; A Ulrich, C Moor, H Vonmont, HR Jordi \& M Lory. "ICP-MS trace element analysis as a forensic tool". Anal. Bioanal. Chem. 378. 2004. 1059-1068; J Aggarwal, JH Mauche \& C Juarez. "Application of heavy stable isotopes in forensic isotope geochemistry: A review". Applied Geochemistry 23. 2008. 2658-2666; J Andrasko, I Kopp \& A Abrink. "Lead isotope ratios in lead smears and bullet fragments and application in firearm investigation". J. Forens. Sci 38. 1993. 1161-1171; A Zeichner, S Ehrlich \& E Shoshai. "Application of lead isotope analysis in shooting incident investigations". Forens. Sci. Int 158. 2006. 52-64.

${ }^{10}$ M Komárek, V Ettler, V Chrastný \& M Mihaljevič. "Lead isotopes in environmental sciences: A review". Environment International 34. 2008. 562-577.

${ }^{11} \mathrm{~S}$ Tamura, A Hokura \& M Oishi. "Lead isotope ratio analysis of bullet samples by using quadrupole ICP-MS”. Bunseki Kagaku Japan Analyst 55. 2006. 827834.

${ }^{12}$ AS Al-Ammar \& RM Barnes. "Improving isotope ratio precision in inductively 
coupled plasma quadrupole mass spectrometry by common analyte internal standardization". J. Anal. At. Spectrom 16. 2001. 327-332; Q Xie \& R Kerrich. "Isotope ratio measurement by hexapole ICP-MS: Mass bias effect, precision and accuracy”. J. Anal. At. Spectrom 17. 2002. 69-74; SF Boulyga, CT Testa, D Desideri \& JS Becker. "Optimisation and application of ICP-MS and alphaspectrometry for determination of isotopic ratios of depleted uranium and plutonium in samples collected in Kosovo". J. Anal. At. Spectrom 16. 2001. 1283-1289.

${ }^{13}$ ER Yourd, JF Tyson \& RD Koons. "On-line matrix removal of lead for the determination of trace elements in forensic bullet samples by flow injection inductively coupled plasma-mass spectrometry". Spectrochimica Acta Part B 56. 2001. 1731-1745.

${ }^{14}$ A Brandone. La Chimica Forense: La rivelazione dei Residui dello Sparo e problematiche connesse. Università degli studi di Pavia, Dipartimento di Chimica Generale, 2004.

${ }^{15}$ Marcuzzo, "Shrapnel” op. cit.

${ }^{16}$ DF Sangster, PM Outridge \& WJ Davis. "Stable lead isotope characteristics of lead ore deposits of environmental significance". Environ. Rev. 8. 2000. 115-147.

${ }^{17}$ SD Mueller, GP Brey, DW Wolf \& Y Lahaye. "Roman lead mining in Germany: Its origin and development through time deduced from lead isotope provenance studies". Journal of Archaeological Science 34. 2007. 1555-1567.

${ }^{18} \mathrm{JH}$ Ward Hierarchical grouping to optimize an objective function. Journal of the American statistical association. 1963. 58(301). 236-244.

${ }^{19} \mathrm{~J}$ Mötz. "The small arms ammunitions of the Habsburg Empire and Austrian Armed Forces from 1866 to 1954. Austrian Military Cartridges". Verlagsbuchhandlung Stöhr, Vol. 1, Vienna, 1996.

${ }^{20} \mathrm{~S}$ Offelli. Le armi e gli equipaggiamenti dell'esercito austro-ungarico dal 1914 al 1918: bandiere reggimentali, decorazioni, armi e dotazioni individuali. Gino Rossato Editore, Vol. II, 2002.

${ }^{21}$ B Meyer. Panorama des Munitions. La Tour-du-Pin: Editions du Portail, 2005. 